\title{
The Horseshoe Crab, Limulus polyphemus: 200 Million Years of Existence, 100 Years of Study
}

\section{Elizabeth A. Walls, ${ }^{1,2}$ Jim Berkson, ${ }^{1,2}$ and Stephen A. Smith ${ }^{1,3}$ \\ ${ }^{1}$ Horseshoe Crab Research Center, Virginia Polytechnic Institute and State University, Blacksburg, Virginia 24061; ${ }^{2}$ Department of Fisheries and Wildlife Sciences, Virginia Polytechnic Institute and State University, Blacksburg, Virginia 24061; ${ }^{3}$ Department of Biomedical Sciences and Pathobiology, Virginia-Maryland Regional College of Veterinary Medicine, Virginia Polytechnic Institute and State University, Blacksburg, Virginia 24061}

\section{TABLE OF CONTENTS}

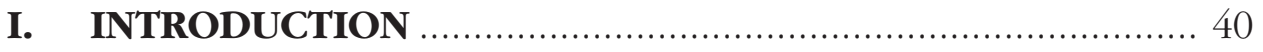

II. GENERAL BIOLOGY, ECOLOGY, AND LIFE HISTORY OF THE HORSESHOE CRAB ..................................................... 41

A. Distribution ........................................................ 42

B. Taxonomy …............................................................ 42

C. Life History .................................................................... 43

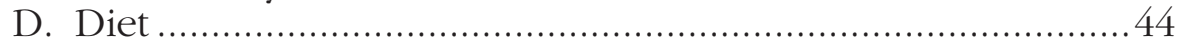

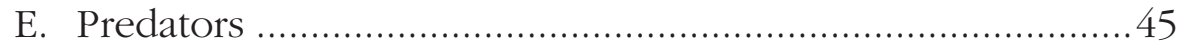

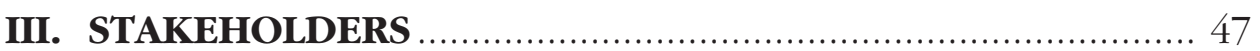

A. Environmentalists and Shorebirds ............................... 47

B. The Horseshoe Crab Commercial Fishery ........................ 50

C. The Biomedical Industry ............................................54

D. Other Important Uses of the Horseshoe Crab ...................58

IV. ECONOMIC IMPACTS ….............................................. 58

V. ALTERNATIVES TO HORSESHOE CRABS ........................ 59

A. The Biomedical Industry ..............................................59

B. The Horseshoe Crab Commercial Fishery …................... 60

VI. HORSESHOE CRAB STATUS AND MANAGEMENT ............6 61

A. The Management Process .......................................... 61

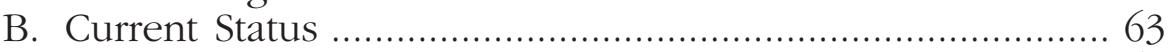

C. Management Actions ...................................................... 64 
D. Stock Assessment Plan 67

E. Management Conclusions

CONCLUSION

ACKNOWLEDGMENTS 69

REFERENCES 70

\begin{abstract}
Management of the horseshoe crab, Limulus polyphemus, is currently surrounded by controversy. The species is considered a multiple-use resource, as it plays an important role as bait in a commercial fishery, as a source of an important biomedical product, as an important food source for multiple species of migratory shorebirds, as well as in several other minor, but important, uses. Concern has arisen that horseshoe crabs may be declining in number. However, traditional management historically data have not been kept for this species. In this review we discuss the general biology, ecology, and life history of the horseshoe crab. We discuss the role the horseshoe crab plays in the commercial fishery, in the biomedical industry, as well as for the shorebirds. We examine the economic impact the horseshoe crab has in the mid-Atlantic region and review the current developments of alternatives to the horseshoe crab resource. We discuss the management of horseshoe crabs by including a description of the Atlantic States Marine Fisheries Commission (ASMFC) and its management process. An account of the history of horseshoe crab management is included, as well as recent and current regulations and restrictions.
\end{abstract}

KEY WORDS: fishery, population dynamics, ecology, living fossil, shorebirds, biomedical industry.

\title{
I. INTRODUCTION
}

Management of the American species of horseshoe crab (Limulus polyphemus) is currently surrounded by controversy. The horseshoe crab is a unique marine invertebrate important to a number of varied user groups. While there have been numerous studies concerning the general biology and life history of the horseshoe crab, information concerning its status and population dynamics is not sufficiently known. As the demand for horseshoe crabs intensifies from each of its user groups, information about its status becomes increasingly necessary. Concern has arisen that horseshoe crab populations are declining in abundance. However, the traditional population and harvest data needed to design appropriate management strategies have historically not been collected for this species. Without accurate population data, future management of this species will become increasingly difficult due to the conflicting needs of its various user groups.

This review article discusses various aspects of the horseshoe crab species. We begin by describing the general biology, ecology, and life history of this organism that has existed in a form virtually unchanged for 200 million years. Many of the aspects of the horseshoe crabs' life history have important influences on their management, and these are highlighted. Following this general description of the species' biology, 
we detail the controversy surrounding the horseshoe crab by describing the various user groups and their stakes in this issue. These include the migratory shorebirds that rely on the eggs of horseshoe crabs for food, the biomedical companies that extract blood from horseshoe crabs to produce a widely used test for the presence of endotoxins, and the commercial fishery that harvests horseshoe crabs for use as bait. In addition to describing the uses and views of the various user groups, the economic importance and impact of the horseshoe crab to its various user groups are discussed. Economic stakes include the effects of eco-tourism associated with bird-watching enthusiasts, the increasing worldwide demand for horseshoe crab blood for endotoxin testing, as well as the increasing demand for horseshoe crabs as bait in commercial fisheries. As the demand for horseshoe crabs increases, so does the need for alternatives to horseshoe crabs. These issues include whether migratory shorebirds could utilize alternate food sources, whether the biomedical product could be produced synthetically, as well as whether decreased numbers or other sources of bait could be used to attract eel and conch.

Historically, management of horseshoe crabs had Historically, been minimal to nonexistent, as they had been considered a "trash-fish", not worthy of limited management resources. For years, they had been ground up and used as fertilizer. Consequently, traditional population data are absent due to the lack of reporting regulations and harvest restrictions associated with the fishery. With concerns of diminishing populations coupled with a trend of expanded use, increased management attention has become a necessity. We discuss the management of horseshoe crabs by including a description of the Atlantic States Marine Fisheries Commission (ASMFC) and its management process. We include an account of the history of horseshoe crab management, as well as recent and current regulations and restrictions. We note that while there is concern that horseshoe crab populations are declining in number, they are presently, by no means, in danger of extinction.

\section{GENERAL BIOLOGY, ECOLOGY, AND LIFE HISTORY OF THE HORSESHOE CRAB}

Horseshoe crabs, the closest living relatives of the trilobites (Shuster, 1982a), have persisted for more than 200 million years (Botton and Ropes, 1987). Unmistakable fossil forms of horseshoe crabs have been found as far back as 500 million years ago, in the latter half of the Paleozoic era (Sekiguchi, 1988). It is thought that the ancestor of the present species probably originated in the Mesozoic waters of Europe (Shuster, 1982b). The present distribution of Limulidae suggests they (or their progenitor species) migrated, one group to the east, one group to the west, as shallow seas disappeared when the European land mass was formed (Shuster, 1982a). Today, horseshoe crabs are found in only two regions of the world. Three species, Tachypleus tridentatus, T. gigas, and Carcinoscorpius rotundicauda, occupy coastal waters of Asia from India to Japan, including waters around the Dutch East Indies and the Philippine Islands. An additional single species is found along the Atlantic coastline of North America from Maine to the Yucatan, from about $19^{\circ} \mathrm{N}$ to $42^{\circ} \mathrm{N}$ (Shuster, 1982a). This "American" species of horseshoe crab, Limulus polyphemus, is the focus of this review. 


\section{A. DISTRIBUTION}

The distribution of Limulus populations along the Atlantic Coast of the United States varies both in overall population size and size of adults, with larger populations and larger animals found in the mid-portion of its range, between Georgia and New York (Shuster, 1978). Smaller populations and animals can be found north of Cape Cod, along the gulf coast of Florida, and the entrances to the Gulf of Mexico (Shuster, 1982a). Horseshoe crabs are most abundant between Virginia and New Jersey (Shuster, 1982a). In New Jersey and Delaware, horseshoe crab abundance decreases with distance north and south of the Delaware Bay (Botton and Haskin, 1984). Temperature appears to be the limiting factor for the northern ranges of Limulus polyphemus and could be a southward limiting factor as well (Shuster, 1982a). Some Limulus polyphemus individuals have been found in European waters, supposedly released by fishermen returning from fishing off the coast of the United States, but no reproductive population has been established there (Shuster, 1982a).

\section{B. TAXONOMY}

The taxonomic classification of the Atlantic Coast horseshoe crab is as follows:

- $\quad$ Phylum: Arthropoda

- $\quad$ Class: Meristomata Dana, 1852

Subclass: Xiphosura Latreille, 1802

- $\quad$ Order: Xiphosurida Latreille, 1802

Suborder: Limulina Richter and Richter, 1929

- $\quad$ Superfamily: Limulacea Zittle, 1885

- $\quad$ Family: Limulidae Zittle, 1885

- $\quad$ Genus: Limulus

- $\quad$ Species: polyphemus $\mathrm{M}_{s} 1 \mathrm{ler}, 1785$

An overall understanding of $L$. polyphemus as well as the three other extant species of horseshoe crabs is important to discerning the natural history of merostome fauna and even the trilobites, as the horseshoe crabs are the sole aquatic survivors from these time periods and can provide a plethora of information not available from the fossil record (Tiegs and Manton, 1958). The horseshoe crab is more closely allied to the ancient sea-scorpion and to modern scorpions and spiders than it is to true crabs, but it was originally mistakenly identified as a crustacean by Europeans (Shuster, 1953). Other common names used in the past include the "horsefoot crab", "horsefeet", "swordtail crab", and "pan crab" (Shuster, 1953), as well as erroneously as "king crab." (Paralithodes camtschatica is the true king crab [Shuster, 1982b]. The external morphology of the horseshoe crab is shown in Figure 1. 


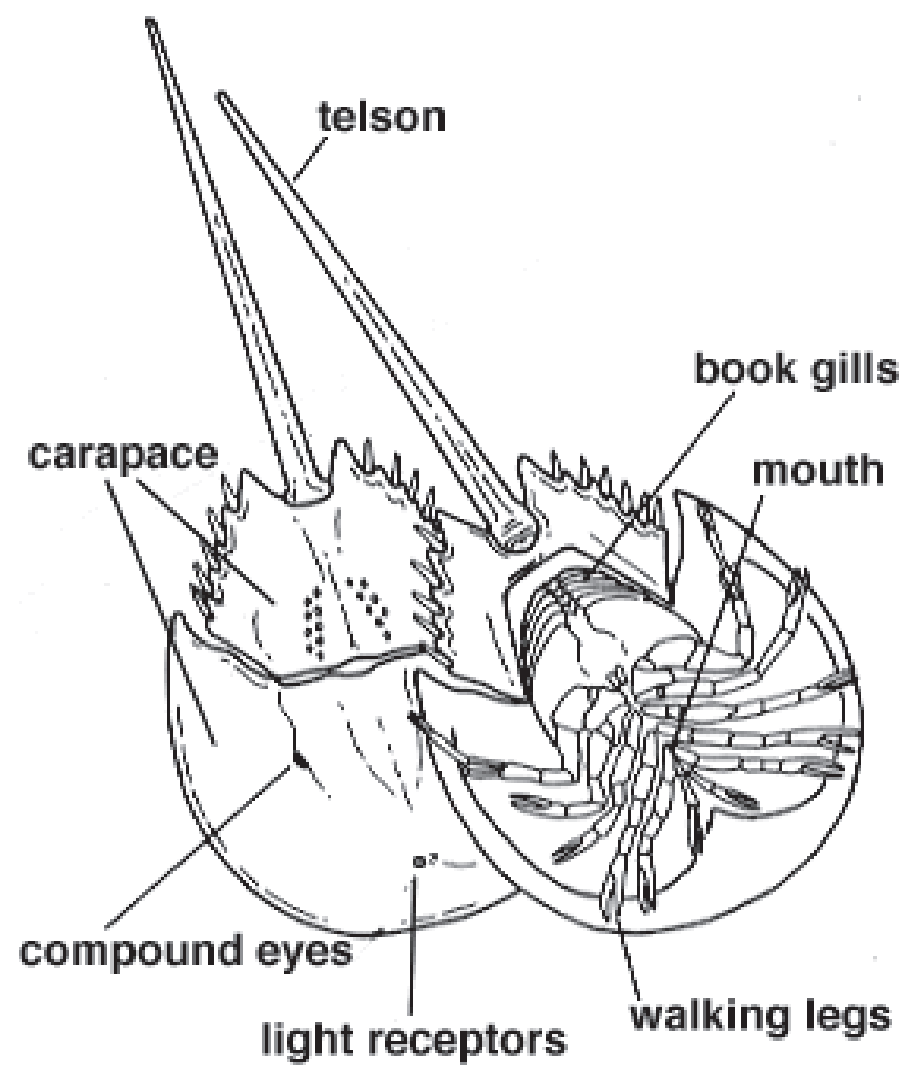

FIGURE 1. The anatomy of a horseshoe crab (Courtesy of Enchanted Learning). (c) National Aquarium in Baltimore.

\section{LIFE HISTORY}

The largest population of Limulus is found in Delaware Bay, and the life history of the population there is generally characteristic of the species (Shuster, 1982b). Horseshoe crabs are considered both ecological and behavioral generalists, tolerant of a broad range of conditions, and capable of reacting to their environment in many ways. However, it has been suggested that characteristics, including behavior, of any one population are not identical to those of another (Shuster, 1982b). There is evidence of genetic variability (Shuster, 1982b), including evidence of gene flow (Saunders et al., 1986; Selander et al., 1970), as well as morphological variation in both size and shape (Riska, 1981). Horseshoe crabs appear to exhibit marked population subdivision even over a relatively small geographic range (Pierce et al., 2000). Gene flow between Delaware Bay and upper Chesapeake Bay populations is extremely limited based on mtDNA analyses (Pierce et al., 2000).

Adult horseshoe crabs winter in deep waters (20 to $60 \mathrm{ft}$ deep) and on the continental shelf (Shuster, 1982b). Increased water temperature and amount of daylight stimulate the adults' migration toward sandy beaches for spawning purposes (Shuster, 1982b). Spawning time varies latitudinally with northern populations of adults migrating to beaches in the late spring, from March to July (Shuster, 1982b). 
The peak migration in the Delaware Bay area generally occurs during the evening new and full moon tides in May and June (Shuster and Botton, 1985; Shuster, 1982b).

Male horseshoe crabs usually outnumber female horseshoe crabs on spawning beaches (Shuster, 1958), creating male-biased sex ratios and male-male competition for mates (Brockmann, 1990). Males use their modified, claw-like pedipalps to grasp onto females' terminal spines (Brockmann and Penn, 1992) as they head from the water to the spawning beaches (Shuster, 1982b). In addition, unattached males also come onto shore looking to find mates (Brockmann and Penn, 1992). Sometimes, a single female may have numerous satellite males trailing behind her within her spawning group (Loveland and Botton, 1992; Penn and Brockmann, 1994). Satellite males show nonrandom distributions around the females, as unattached males appear to be preferentially attracted to some females over others (Brockmann, 1996). Several studies have investigated the male horseshoe crabs' use of vision when finding mates (Powers et al., 1991; Herzog and Barlow, 1992; Herzog et al., 1996). Hassler and Brockmann (2001) demonstrated that male horseshoe crabs use both chemical and visual cues when locating mates.

Each adult female horseshoe crab may produce at least 88,000 mature eggs, although this number is highly variable (Shuster, 1982a). Females dig an excavation below their body and deposit their eggs in clumps within the intertidal zone at depths ranging from 5 to $30 \mathrm{~cm}$ (Rudloe, 1979; Brockmann, 1990). Each clump contains approximately 3650 eggs, on average (Shuster and Botton, 1985), which are fertilized when waves wash spermatozoa released by males into the area of the eggs (Shuster, 1982b). It has been suggested that adult horseshoe crabs can spawn multiple times each season (Shuster, 1950). Weather can negatively affect spawning activity by disrupting spawning sites, driving animals off the beach, diminishing the number of pairs able to spawn, or by preventing the animals from coming to the beach at all (Shuster, 1982a). One study reported that the numbers of spawners in the Cape May, New Jersey, area vary, and that when the numbers are low in that area they are conversely numerous on the Delaware shores (Fowler, 1908). Another negative impact on spawning occurs as some of the eggs on the sandy shore and in shallow waters are eaten by shorebirds, shrimp, and a number of species of small fish (Shuster, 1982a).

After the eggs incubate for 2 to 4 weeks, larvae begin to emerge (Jegla and Costlow, 1982; Sekiguchi et al., 1982; Botton, 1995), although some larvae may not hatch until the following spring, spending their winter buried under the sand (Botton et al., 1992). Larvae enter the water as they are freed from their clusters by a combination of churning wave action and from their own digging and burying (Shuster, 1982b). After hatching, the horseshoe crabs' lives consist mainly of foraging for food and growing (Shuster, 1982b). As the horseshoe crabs grow, they gradually move several kilometers from their natal beaches into deeper waters (Shuster, 1978), where they will begin their spawning migration once they reach adulthood (Shuster, 1982b).

Horseshoe crabs molt numerous times as they grow from their larval stage, shedding their exoskeleton at least 16 or 17 times before reaching sexual maturity (Shuster, 1950). The molting process occurs during the warm-water months, and becomes more difficult and time consuming at each growth stage (Shuster, 1982a). Horseshoe crabs require 9 to 10 years to reach sexual maturity (Shuster, 1958), and at this time, apparently cease to molt and grow (Shuster, 1982a). They are fairly long-lived, and some may reach a maximum age of 20 years (Shuster, 1958). It is difficult to determine adult age directly, so it must be approximated using indirect methods. This is generally accomplished through tagging, by 
aging any epibionts (symbiotic organisms) present on the shell (Botton and Ropes, 1988), or by examining the type and site of carapace wear and the size and kind of epibionts. Using the appearance of the carapace as a general indicator of the age of an individual is based on a simple rationale: Because adults do not molt, their exposure to a sandabrasive environment, the larvae of epibionts, marks left from previous spawning activity (Walls, 2001), and diseases of the shell increase with age. Three categories are commonly used to describe the ages of adult horseshoe crabs. These categories include:

- Young Adults: Carapace is lustrous with few, if any, scratches or epibionts. Virgin males can be identified by the atrophied nonmoveable chela, which break off after first mating. Virgin females can be identified by a pristine shell with no mating scars.

- Middle-aged Adults: Lustrous sheen of carapace is being eroded away, as a black layer of shell becomes exposed. Both genders exhibit increasingly extensive scratches on their carapace. Female horseshoe crabs have large black areas on the middle and posterior portions of their abdomens that are mating scars resulting from abrasion during mating. "Pressure spots" are evident where the claspers of the male attach to the trailing edges of the female's abdomen during spawning. Epibionts are usually present on the carapace.

- Old-aged Adults: Carapace tends to be almost completely blackened, and in the case of extreme erosion the black layer is also worn away, exposing a brownish-colored layer that is often tinged with green. The shell of the horseshoe crab is thin and can be easily depressed. Epibionts are almost always present and may have reached large sizes.

Source: (C. N. Shuster, Jr., personal communication, 1999)

\section{DIET}

An adult horseshoe crab diet consists of several species of bivalve mollusks (including razor clam (Ensis spp.), macoma clam (Macoma spp.), surf clam (Spisula solidissima), blue mussel (Mytilus edulis), wedge clam (Tellina spp.), fragile razor clam (Siliqua costata), soft-shelled clam (Mya arenaria)), and worms (polychaete Nereis spp. and nemertean Cerebratulus spp.) (Shuster, 1982a; Botton, 1984a, b; Botton and Haskin 1984). Botton (1984a) also found vascular plant material in nearly $90 \%$ of horseshoe crabs sampled. To eat, L. polyphemus digs after its food, grasping its prey with pincer-tipped legs (Shuster, 1982a). The food is then crushed between the legs and pushed forward into the mouth (Shuster, 1982a). A more detailed description of feeding can be found in other sources (Manton, 1977; Scott and Seigel, 1992; Wyse and Dwyer, 1973).

\section{E. PREDATORS}

Horseshoe crabs face dangers from a variety of predators throughout their lifecycle. These include mollusks, crustaceans, fish, leopard sharks, eels, birds, sea turtles, 
and, maybe most importantly, man. A partial list of organisms known to prey on horseshoe crabs during various stages of their lives is given in Table 1 (Shuster, 1982a; Keinath et al., 1987; deSylva et al., 1962).

TABLE 1

Organisms Known to Prey on the Horseshoe Crab, Limulus polyphemus

\begin{tabular}{|c|c|c|c|}
\hline Group: & Species: & Group: & Species: \\
\hline \multirow[t]{12}{*}{ Birds } & $\begin{array}{l}\text { Semipalmated plover } \\
\text { (Charadrius semipalmatus) } \\
\text { [eggs] }\end{array}$ & Fish & $\begin{array}{l}\text { Silver Perch (Bairdiella } \\
\text { chrysura) [eggs and larvae] }\end{array}$ \\
\hline & $\begin{array}{l}\text { Black-Bellied plover (Pluvialis } \\
\text { squatarola) [eggs] }\end{array}$ & & $\begin{array}{l}\text { Weakfish (Cynoscion regalis) } \\
\text { [eggs and larvae] }\end{array}$ \\
\hline & $\begin{array}{l}\text { Pectoral sandpiper (Calidris } \\
\text { melanotos) [eggs] }\end{array}$ & & $\begin{array}{l}\text { Northern kingfish } \\
\text { (Menticirrhus saxatilis) [eggs } \\
\text { and larvac] }\end{array}$ \\
\hline & $\begin{array}{l}\text { Least sandpiper (Calidris } \\
\text { minutilla) [eggs] }\end{array}$ & & $\begin{array}{l}\text { Atlantic silverside (Menidia } \\
\text { menidia) [eggs and larvae] }\end{array}$ \\
\hline & $\begin{array}{l}\text { Semipalmated sandpiper } \\
\text { (Calidris pusilla) [eggs] }\end{array}$ & & $\begin{array}{l}\text { Summer flounder } \\
\text { (Paralichthys dentatus) [eggs } \\
\text { and larvae] }\end{array}$ \\
\hline & $\begin{array}{l}\text { Sanderling (Calidris alba) } \\
\text { [eggs] }\end{array}$ & & $\begin{array}{l}\text { Winter flounder } \\
\text { (Pseudopleuronectes } \\
\text { americanus) [eggs and larvae] }\end{array}$ \\
\hline & $\begin{array}{l}\text { Laughing Gull (Larus atricilla) } \\
\text { [eggs] }\end{array}$ & & $\begin{array}{l}\text { Leopard Shark (Triakis } \\
\text { semifasciata) [Adults] }\end{array}$ \\
\hline & $\begin{array}{l}\text { Boat-tailed grackle (Cassidix } \\
\text { major) [eggs] }\end{array}$ & & Catfish [eggs] \\
\hline & $\begin{array}{l}\text { Red knots (Calidris canutus) } \\
\text { [eggs] }\end{array}$ & & $\begin{array}{l}\text { Puffers (Tetraodontidae) } \\
\text { [juveniles] }\end{array}$ \\
\hline & $\begin{array}{l}\text { Ruddy turnstones (Arenaria } \\
\text { interpres) [eggs] }\end{array}$ & & $\begin{array}{l}\text { Devil Ray (Mobula } \\
\text { hypostoma) }\end{array}$ \\
\hline & $\begin{array}{l}\text { Herring gull (Larus } \\
\text { argentatus) [adults] }\end{array}$ & & Swordfish (Xiphiidae) \\
\hline & $\begin{array}{l}\text { Greater black-backed gull } \\
\text { (Larus marinus) [adults] }\end{array}$ & & $\begin{array}{l}\text { Mullet (Mugilidae) [eggs and } \\
\text { larvae] }\end{array}$ \\
\hline \multirow[t]{6}{*}{ Arthropods } & $\begin{array}{l}\text { Sand Shrimp (Crangon } \\
\text { septemspinosa) [eggs] }\end{array}$ & & $\begin{array}{l}\text { Striped bass (Morone } \\
\text { saxatilis) [eggs] }\end{array}$ \\
\hline & $\begin{array}{l}\text { Fiddler crab (Uca pugnax) [first } \\
\text { and second tailed stages] }\end{array}$ & & $\begin{array}{l}\text { White perch (Morone } \\
\text { americana) [eggs] }\end{array}$ \\
\hline & $\begin{array}{l}\text { Blue crab (Callinectes sapidus) } \\
\text { [juveniles] }\end{array}$ & & $\begin{array}{l}\text { American eel (Anguilla } \\
\text { rostrata) [eggs and larvae] }\end{array}$ \\
\hline & $\begin{array}{l}\text { Green crab (Carcinides } \\
\text { maenus) [juveniles] }\end{array}$ & Mollusks & (Melongena spp.) [adults] \\
\hline & $\begin{array}{l}\text { Spider crab (Libinia spp.) } \\
\text { [juveniles] }\end{array}$ & Reptiles & $\begin{array}{l}\text { Loggerhead sea turtle } \\
\text { (Caretta caretta) [adults] }\end{array}$ \\
\hline & Amphipods [larvae] & & \\
\hline
\end{tabular}

Source: (Shuster, 1982a; Keinath et al., 1987; deSylva et al., 1962) 


\section{STAKEHOLDERS}

\section{A. ENVIRONMENTALISTS AND SHOREBIRDS}

The relationship of horseshoe crabs with the spring migration of hemispheric shorebirds has received attention since the early 1980s, beginning with the New Jersey Audubon Society's surveys of Delaware Bay beaches (Clark, 1996). Each spring, at least 11 species of birds (Charadriiformes: Charadridae and Scolopacidae) feed on eggs deposited by spawning horseshoe crabs along the shorelines in this area, in both Delaware and New Jersey (Shuster, 1982a; Myers, 1986) (Figure 2). These species include red knots (Calidris canutus), ruddy turnstones (Arenaria interpres), sanderlings (C. alba), and semipalmated sandpipers (C. pusilla) (Shuster, 1982a), as well as dunlins (C. alpina) and dowitchers (Limnodromus spp.) (Dunne et al., 1982; Castro and Myers, 1993), and laughing gulls (Larus atricilla) (Botton, 1984b), all of which use the Delaware Bay region as a staging area during their migration. According to Botton et al. (1994), staging areas serve as intermediate stopover points for the birds to feed before continuing their migration. An estimated 425,000 to 1,000,000 birds stop in Delaware Bay staging areas during May and June (Myers, 1981, 1986; Myers et al., 1987; Shuster, 1982a; Clark et al., 1993), as they travel from their South American wintering grounds to their Arctic breeding grounds (Myers, 1986). The timing of their migration north is critical, as the birds need to reach the Arctic while the snow is melting to ensure their eggs will hatch in time for the annual insect hatch, which comprises the primary diet of the young shorebirds (Clark, 1996).

The migrating shorebirds arrive in the Delaware Bay area simultaneously as hundreds of thousands of horseshoe crabs emerge from the Delaware Bay to lay their eggs in the sandy beaches. Peaks in both shorebirds migrating through the bay area and horseshoe crab spawning tend to occur during the third or fourth week in May (Clark, 1996). Female horseshoe crabs come ashore at high tide with males in amplexus, accompanied by unattached "suitor" males (Botton and Loveland, 1989). They deposit up to 20 egg clusters, each with an average of 3650 eggs about 10 to $20 \mathrm{~cm}$ below the sand's surface (Shuster and Botton, 1985). This depth is beyond the reach of most shorebirds (Clark, 1996), but wave action and burrowing by spawning horseshoe crabs move some of the eggs toward the sand's surface (Botton et al., 1994). It is these eggs that have been disturbed from the horseshoe crab egg clusters that most shorebirds feed on (Clark, 1996). For example, red knots (C. canutus) and sanderlings (C. alba) have the longest bills of the more prevalent shorebirds $(3.5 \mathrm{~cm}$ and $2.5 \mathrm{~cm}$, respectively) and forage in moist sand where their reach is not much deeper than their bills (Clark, 1996). Thus, they cannot reach deep enough in the sand to consume viable eggs remaining in the egg clusters. Clark (1996) points out a possible exception, as ruddy turnstones (A. interpres) are capable of reaching eggs at slightly deeper depths $(5$ to $10 \mathrm{~cm}$ ) by excavating holes in the sand, and therefore could be reaching viable clusters of eggs.

In order to complete their 3000 to 4000 mile journey to the Arctic, the shorebirds need to feed wherever possible (Clark, 1996). As food is often scarce along their migration route, Delaware Bay, with its vast supply of horseshoe crab eggs, is a crucial stopover for the shorebirds to obtain food and rest (Clark et al., 


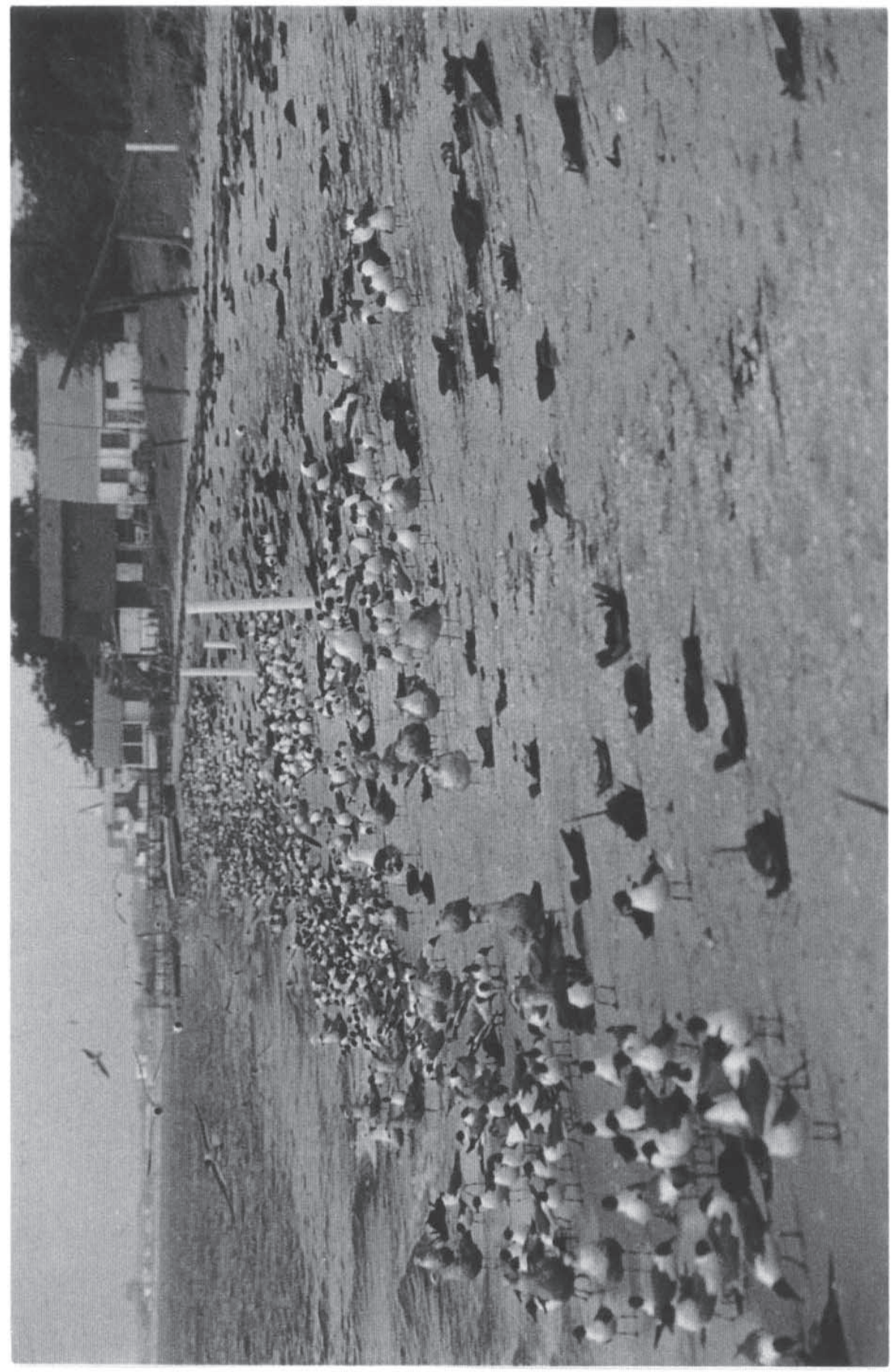

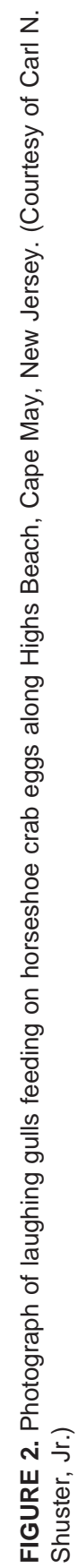


1993). Castro et al. (1989) report that during the 2 to 3 week time period the birds stay on Delaware Bay, they undergo weight gains of at least $40 \%$ of their body weight. It has been estimated that all shorebirds consume $5526.2 \times 10^{6} \mathrm{~kJ}$ of energy for their trip, equivalent to approximately 539 metric tons of horseshoe crab eggs (Castro and Myers, 1993). One reason this number is so large is because of the low metabolic efficiencies of the birds, which Castro et al. (1989) attribute to the low number of eggs that are actually broken down when passing through the birds' gastrointestinal tracts, as the egg's cuticle resists chemical and enzymatic digestion. The sanderling (C. alba) averages a metabolic efficiency of 38.6\% +/- 1.0\% (Castro et al., 1989). The value of assimilation efficiency is assumed to be similar for all species, because assimilation efficiency seems to be primarily a function of food consumed (Castro et al., 1989; Castro and Myers, 1993). Thus, it has been estimated that 1,820,000 female horseshoe crabs are required to feed Delaware Bay's migratory birds (Castro and Myers, 1993). These calculations assume that shorebirds are feeding exclusively on horseshoe crab eggs (Castro and Myers, 1993), but they may augment their diet with other food sources (Botton, 1984a), including invertebrates (Clark, 1996).

In addition to birds feeding on the eggs of horseshoe crabs, there is also evidence of birds feeding on adult horseshoe crabs (Botton and Loveland, 1989, 1993). Botton and Loveland (1993) report that both herring gulls (Larus argentatus) and great black-backed gulls (L. marinus) prey on live and dead horseshoe crabs stranded on the beaches of the Delaware Bay. Horseshoe crabs become stranded when tides recede or when they cannot right themselves after getting turned over by wave action (Botton and Loveland, 1989) or mating, a problem that seems to affect older horseshoe crabs more so than younger ones (Penn and Brockmann, 1995). It has been estimated that 7760 horseshoe crabs per $\mathrm{km}$ may be killed by predatory activities along the New Jersey shore of the Delaware Bay (Botton and Loveland, 1993). Due to the high number of horseshoe crab eggs eaten by shorebirds, combined with predation on adult horseshoe crabs, it is likely that shorebirds have an impact on horseshoe crab numbers. The extent of this impact is not known.

Horseshoe crab population numbers also affect shorebird numbers. As Clark (1996) asserts, to prevent threats to shorebirds, horseshoe crab populations must be maintained above minimal functioning levels. Shorebirds face threats of human disturbance, oil spills or other chemical spills, as well as habitat degradation and loss (Clark, 1996). Hence, maintaining adequate food sources is imperative. As horseshoe crabs and surface egg availability are not encountered in comparable quantities anywhere else along the Atlantic Coast, the Delaware Bay region is of utmost importance to the shorebirds (Berkson and Shuster, 1999). In addition, the migration phenomenon in the Delaware Bay area has become an eco-tourism event, attracting bird-watchers and contributing to the local economies in the Delaware Bay region (Clark, 1996).

Despite their many predators and a variety of other threats to their populations, horseshoe crabs have existed for millions of years. However, this could be changing, as the horseshoe crab commercial fishery is the latest threat jeopardizing their population size. 


\section{B. THE HORSESHOE CRAB COMMERCIAL FISHERY}

Before the latter half of the 20th century, horseshoe crabs were commercially harvested for fertilizer and livestock feed. From the 1870s to the 1960s, catch records in the Delaware Bay region exhibited a progressive decline from a maximum of over 4 million horseshoe crabs per year to less than 100,000 (Shuster and Botton, 1985) (Figure 3). Horseshoe crabs are no longer harvested for fertilizer or livestock feed, not because of fishery restrictions, but because of a decline in the number of horseshoe crabs, competition with other fertilizers, and public complaints of odor (Berkson and Shuster, 1999). Aside from their use as fertilizer and livestock feed, traditionally they have been considered a nuisance to most commercial fishers, as they can easily become trapped in pound nets and caught in seines and trawls (Berkson and Shuster, 1999). In fact, many commercial fishers have employed the use of special gear on their trawlers designed to exclude horseshoe crabs from their catch.

During the 1950s and 1960s, the horseshoe crab commercial fishery was minimal along the United States' Atlantic coast. Reports of increases of regional horseshoe crab populations during this time exist, and one describes at least 13-fold increases in population size on Highs Beach, New Jersey (Loveland et al., 1996).

During the second half of the 20th century, a commercial fishery on horseshoe crabs developed to provide bait for use in catching American eel (Anguilla rostrada) and whelk (commonly referred to as "conch" [Busycon spp.])) (HCTC, 1998). Female horseshoe crabs are preferred for use in the eel pot fishery due to the eel's preference for certain chemical odors unique to the egg-laden females (HCTC, 1998). This has obvious consequences for the sex distribution of the population (Loveland et al., 1996). Both male and female horseshoe crabs are used in the conch pot fishery (HCTC, 1998). In addition, horseshoe crabs serve as bait for the catfish (Ictaluridae) fishery, although to a lesser extent.

A variety of methods are employed by the fishers to obtain horseshoe crabs. Horseshoe crabs are caught by trawl, dredge, hand, and gillnet (HCTC, 1998). An entire spawning beach of horseshoe crabs can easily be harvested in the hand fishery simply by gathering all of the horseshoe crabs that have congregated in the shallow waters and sandy beaches. Because of the species prevalence in the waters in the mid-Atlantic region, fishery effort is concentrated within the mid-Atlantic coastal and surrounding federal waters (HCTC, 1998). However, a significant fishery has been growing in the New England area as well (Schrading et al., 1998).

The horseshoe crab commercial fishery increased dramatically beginning around 1990 (Loveland et al., 1996). As the demand for conch has grown worldwide, so too has the demand for horseshoe crabs as bait (Berkson and Shuster, 1999). Although data for commercial landings for horseshoe crabs are collected by the National Marine Fisheries Service (NMFS), their records are often incomplete and conversions between numbers landed and pounds landed have been "quite variable" (HCTC, 1998). However, despite inaccuracies in the data, all reported landings data show substantial increases between 1990 and 1996 (HCTC, 1998) (Figure 4). This increase in landings has been attributed to a combination of improvements in harvest reporting requirements, as well as an increase in fishing effort. In Delaware, effort (measured as the number of hand permits issued) increased sixfold between the 


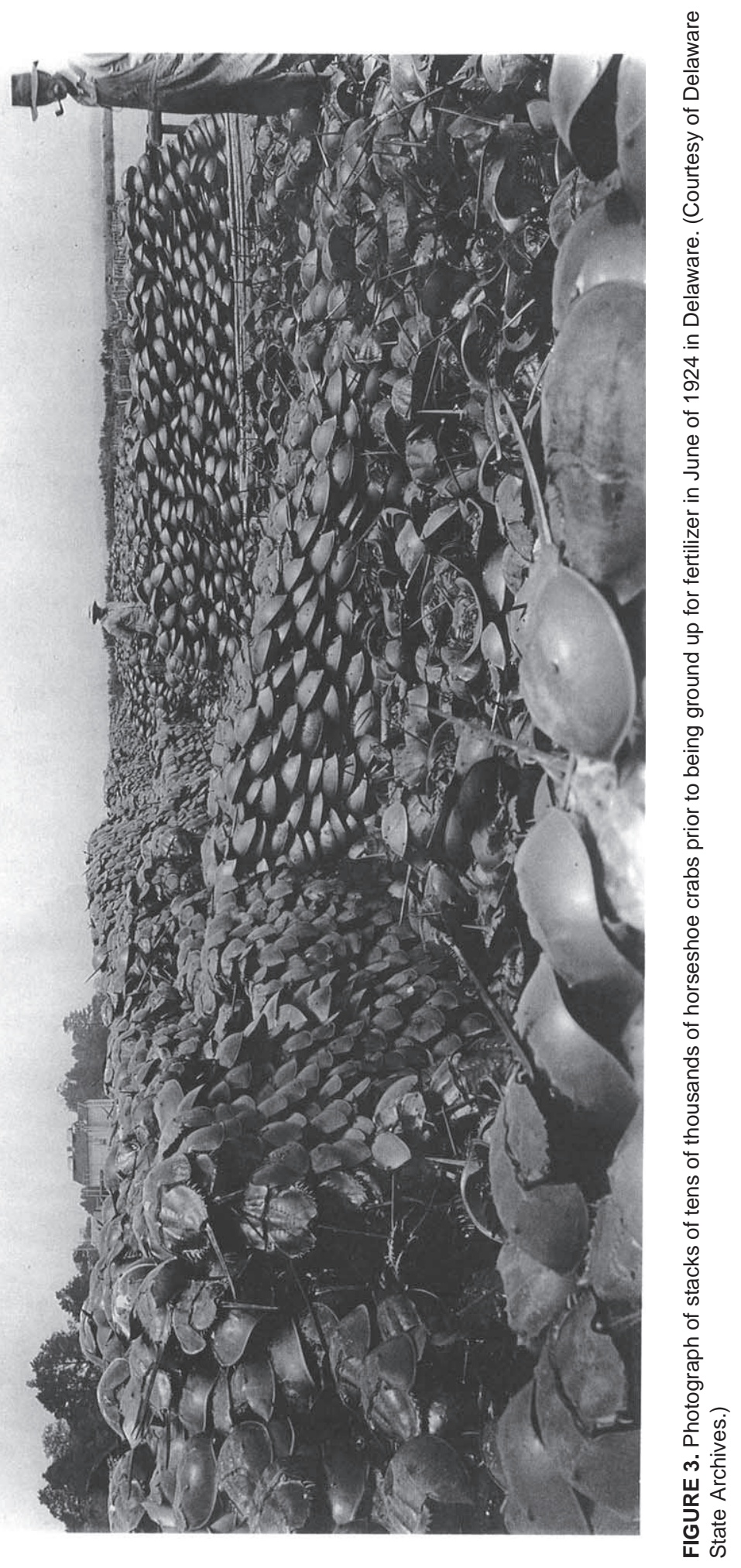




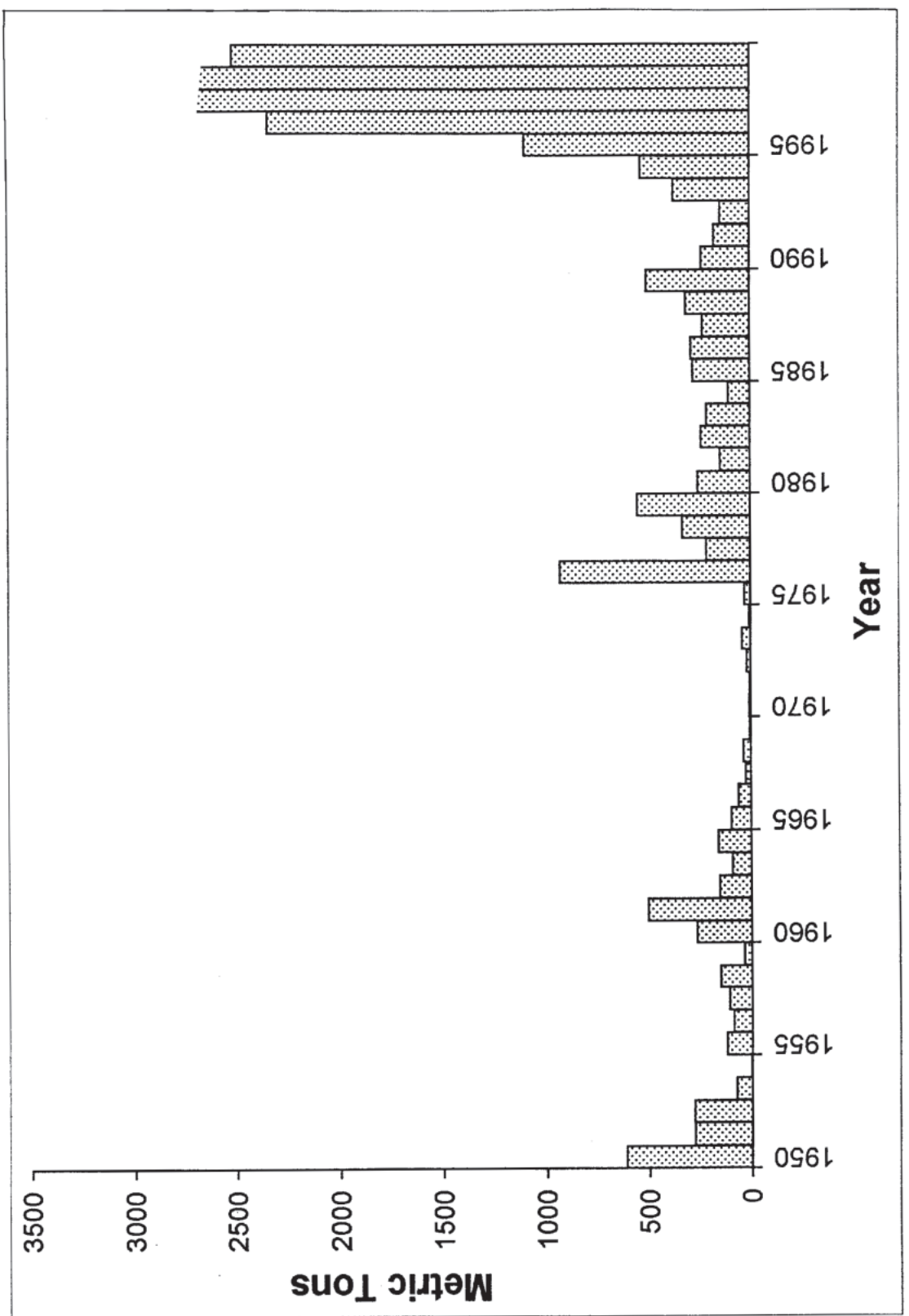

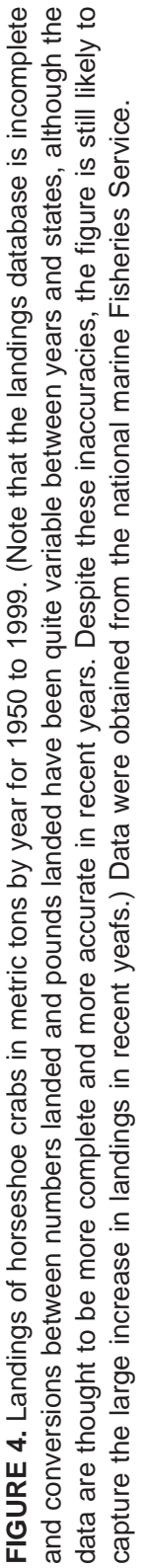


years 1991 and 1997 (HCTC, 1998) (Figure 5). In addition, mandatory reporting of landings in Delaware showed that landings nearly doubled between the years 1995 and 1997 (HCTC, 1998). Overall, coastwide landings averaged over 1 million horseshoe crabs between 1989 and 1992, but grew to over 2 million in 1993 (Loveland et al., 1996).

\section{Delaware's Commercial Horseshoe Crab Effort}

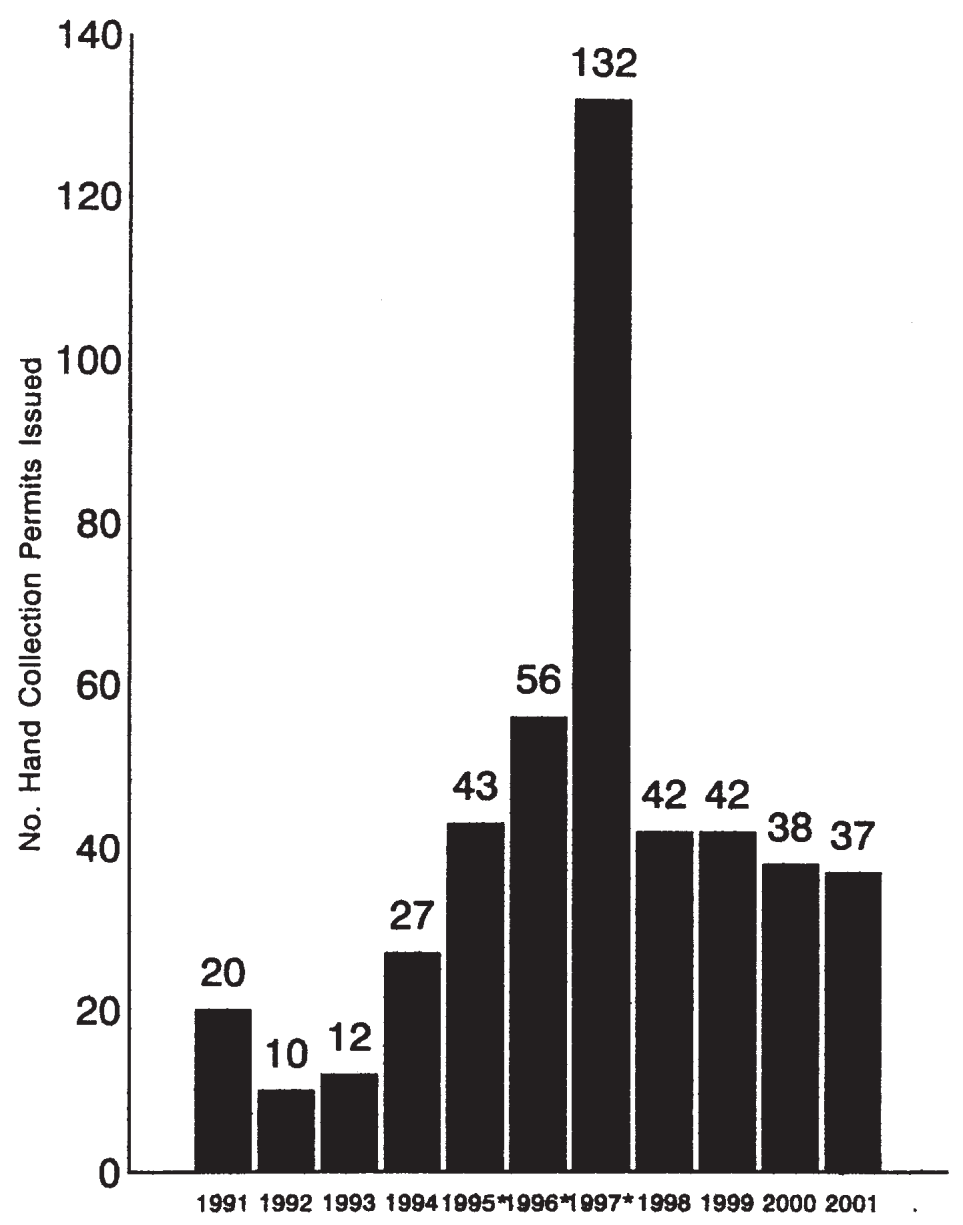

FIGURE 5. Number of hand collection permits issued in Delaware for the years 1991-2001. Data were obtained from the Delaware Division of Fish and Wildlife. 
Relative to other fisheries, fishing regulations for horseshoe crabs historically have been minimal to nonexistent (Schrading et al., 1998). In addition, historical data are sparse and inconsistent. Management regulations and reporting restrictions for the horseshoe crab commercial fishery are changing. The commercial bait fishery is not the sole industry affecting horseshoe crabs. Pharmaceutical companies also utilize the horseshoe crab resource and their effects must also be examined.

\section{THE BIOMEDICAL INDUSTRY}

The clotting of Limulus blood was first described by W.H. Howell in 1885, and soon thereafter the Marine Biological Laboratory in Woods Hole, Massachusetts, was created to serve as the center for Limulus research (Novitsky, 1984). At Woods Hole, Leo Loeb continued the work of Howell to describe in great detail the blood and circulation of blood in the horseshoe crab (Novitsky, 1984). A thorough description of the circulatory system and blood of the horseshoe crab can be found in the Federal Energy Regulatory Commission's February, 1979 monthly magazine (FERC, 1979). What could be considered the greatest discovery concerning the horseshoe crab occurred during the 1950s when Frederik Bang discovered the causative agent for the clotting of Limulus blood, Limulus Amebocyte Lysate (Novitsky, 1984; Farrell and Martin, 1996). Limulus Amebocyte Lysate, or LAL, comprises the current medical use of horseshoe crabs today (Berkson and Shuster, 1999). During the 1970s, the effort of three scientists, Donald Hochstein, Edward B. Seligmann, Jr., and James Cooper, initiated governmental recognition of LAL and acceptance of LAL by the Food and Drug Administration (Novitsky, 1984). This clotting agent, obtained from horseshoe crab blood cells, is used to detect minute amounts of bacterial toxins (Novitsky, 1984). The purified LAL has the capability of detecting one millionth of a billionth of a gram of endotoxin in less than $1 \mathrm{~h}$ (Mikkelsen, 1988).

The LAL test represents one of a number of pharmacologically significant, chemical constituents found in marine flora and fauna (Mikkelsen, 1988). A wealth of significant compounds have been isolated from marine animals. These include compounds derived from the sea cucumber used in anti-cancer chemotherapy, hormones from gorgonians used for birth control, against peptic ulcers and asthma and lowering blood pressure, as well as compounds derived from red algae that can prevent atherosclerosis (Mikkelsen, 1988). The discovery, commercialization, and use of LAL has been an important improvement to the pharmaceutical industry. Prior to the use of LAL, compounds were tested for the presence of endotoxins in a variety of ways that involved living animals or living parts of animals (Mikkelsen, 1988). Thus, LAL provides a means to detect endotoxins without having to kill or disable animals (Mikkelsen, 1988).

Limulus Amebocyte Lysate is extremely useful in detecting those toxins that cause fever - the bacterial "pyrogens" or endotoxins. Endotoxins occur as a structural component of the cell wall of a large group of bacteria known as Gramnegative (Novitsky, 1984). Most aquatic bacteria are of the Gram-negative variety, as studies at the Woods Hole Oceanographic Institution have shown that seawater contains over 1 million Gram-negative bacteria per milliliter and that almost 1 billion bacteria can be found per gram of sand near the shore (Novitsky, 1984). Thus, the horseshoe crab habitat contains vast amounts of endotoxin, making it no coinci- 


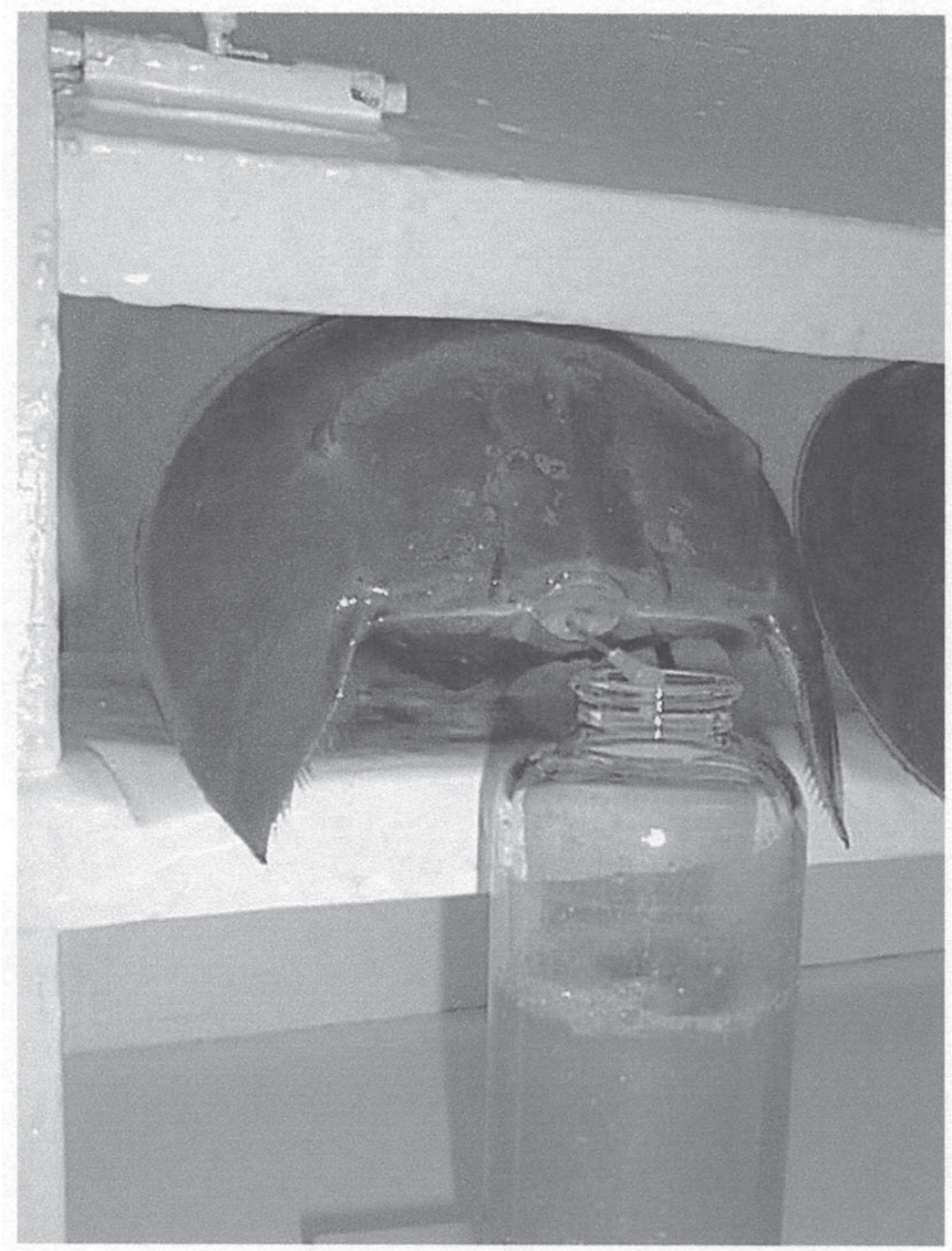

FIGURE 6. Photograph of a horseshoe crab being bled on a bleeding rack at a biomedical company. (Photographer was anonymous.)

dence that the horseshoe crab evolved a vital system to protect itself against endotoxins.

The horseshoe crab blood includes amebocytes that contain the clotting enzymes and other factors with the ability to immobilize and engulf an endotoxin (Mikkelsen, 1988). When exposed to endotoxin, the amebocytes change shape, adhere to the sides of the vascular channels, and form the resultant gel clot (Shuster, 1982a). This phenomenon is at the heart of the LAL assay, as formation of a clot shows presence of endotoxin.

The LAL procedure is simple to perform. Blood of the horseshoe crab is extracted via cardiac sinus puncture with a large gauge needle (Figure 6) and placed in a centrifuge where the blood is spun at low speed. This results in the separation 
of amebocytes in the pellet from the blue, cell-free haemolymph that comprises the supernatant. The latter is discarded, while the intact amebocytes are homogenized and centrifuged at high speed. After centrifugation, the cell debris forms a pellet and the desired clotting factors are found in the resulting supernatant. This resulting supernatant is termed the Limulus Amebocyte Lysate. The compound is transferred to sterile vials and frozen in an inactive form. To activate raw LAL, additional ions are added in the form of sodium and calcium or magnesium salts, a patented solvent extraction is performed to improve the reagent's sensitivity, and the final liquid LAL is then freeze-dried for long-term stability (Novitsky, 1984).

To perform the actual sterility test, several methods can be utilized. Each begins by mixing a small amount of LAL reagent with an equivalent amount of solution in question in a glass test tube. In one case, the mixture is incubated (usually 1 hour at $37^{\circ} \mathrm{C}$ ), and then examined for the presence of a gel or clot (Novitsky, 1984). A clot indicates the presence of endotoxin or pyrogen. Another method involves measuring the rate of turbidity in the mixture before the formation of a clot (R. Berzofsky, personal communication). A third method, the chromogenic substrate method, involves the reagent turning a yellow color after mixing. The degree of yellow coloration is measured after a fixed time period to indicate the presence of endotoxin or pyrogen ( $\mathrm{R}$. Berzofsky, personal communication). Representative samples from batches of pharmaceutical products are tested in one of the above manners before products are distributed to physicians or pharmacies.

The major use of LAL today is in the detection of endotoxins in pharmaceutical products (Novitsky, 1984). Since its original description, however, it has also been used in the diagnosis of endotoxemia in conjunction with cirrhosis, cancer, meningitis, eye disease, dental problems, gonorrhea, boutonneuse fever, and water-quality analysis (Rudloe, 1983), as well as urinary tract infections (Novitsky, 1984). In addition, new applications for LAL continue to be found, including the detection of bacterially contaminated meat, fish, and dairy products, including frozen items (Novitsky, 1984).

The effects of the blood extraction process on a horseshoe crab have been studied by several scientists. From aquarium studies, it is known that a horseshoe crab that has undergone the blood extraction process regains its blood volume very quickly, usually in 3 to 7 days (Novitsky, 1984). The amebocytes regenerate at a slower rate, requiring up to 4 months before cell counts equal those obtained prior to bleeding (Novitsky, 1984). As stated previously, these amebocytes are required for the LAL clotting factors. Amounts of blood taken from an individual horseshoe crab can range from 100 to $300 \mathrm{~mL}$ per animal (Rudloe, 1983). The maximum available volume is 200 to $300 \mathrm{~mL}$, which alludes to questions concerning mortality associated with blood extraction (Rudloe, 1983). Following the blood extraction process, biomedical companies return the bled horseshoe crabs back to the location from which they were captured. Prior to Rudloe's 1983 study, little information existed on the survival of bled horseshoe crabs under field conditions, even though horseshoe crabs had been used for LAL since the 1950s (Novitsky, 1984; Rudloe, 1983). The ability of horseshoe crabs to resist predators, disease, and other stresses encountered in the wild is unknown, and delayed mortality of bled animals was presented as a possible problem (Rudloe, 1983).

Rudloe's study was the first of its kind to ascertain the impact of blood extraction for LAL production on horseshoe crabs in their natural environment. Rudloe studied 
horseshoe crabs off of the Gulf Coast of Florida in St. Joseph Bay. Approximately 10,000 mature horseshoe crabs were collected, described and tagged, and half were bled, while half served as a control. By examining rate of tag recovery, Rudloe found that bleeding increased mortality by $10 \%$ during the first year after bleeding, and by $11 \%$ during the second year (Rudloe, 1983).

The effect of blood extraction for production of LAL on the survival of horseshoe crabs was also studied by Thompson (1998) in South Carolina. In Thompson's study, during June of 1996, 40 horseshoe crabs were harvested from Bull's Bay, South Carolina. Twenty of these horseshoe crabs, 10 male and 10 female, were processed at a commercial LAL processing facility, while 20 were kept as controls. The animals were placed in a 20-f diameter tank and observed for a period of 1 week. During the observation period, three bled female horseshoe crabs died. Thompson estimated the resultant rate of mortality for bled horseshoe crabs to be $15 \%$ in this onetime study.

Further study of the effect of blood extraction on the survival of horseshoe crabs was done by Walls and Berkson (2000) in Chincoteague, Virginia. In this study during the summer of 1999, horseshoe crabs were caught in the Atlantic Ocean off the coasts of Chincoteague, Virginia, and Ocean City, Maryland. Twenty of the horseshoe crabs were bled at a commercial LAL processing facility, while 20 were kept as controls. The animals were placed into a recirculating marine aquaculture system and observed for a 2 -week period. During the observation period, 3 of the 20 bled horseshoe crabs died. Walls and Berkson estimated a 15\% increase in mortality of bled horseshoe crabs over unbled horseshoe crabs in this study. Preliminary results from their full 3-year study indicate a much lower mortality rate.

At the time of Rudloe's 1983 study, 30,000 horseshoe crabs were used per year for the acquisition of LAL (Rudloe, 1983). In 1989, 130,000 horseshoe crabs were bled (HCTC, 1998). The Food and Drug Administration (FDA) estimates that 260,000 horseshoe crabs were caught, bled, and returned to the ocean by biomedical companies in 1997 (HCTC, 1998). There is an upward trend in the number of horseshoe crabs used by the biomedical industry, although growth has slowed in recent years (Berkson and Shuster, 1999). In South Carolina, for instance, the biomedical industry's use of horseshoe crabs has resulted in over a 300\% increase in number of horseshoe crabs caught since reporting requirements were established in 1991 (Thompson, 1998).

The biomedical companies are regulated in their blood extraction process, although each LAL producer has a unique operation in processing and handling of horseshoe crabs. Historically, the FDA required that horseshoe crabs caught for bleeding must be released within $72 \mathrm{~h}$ of capture (HCTC, 1998). There are currently 5 biomedical companies producing LAL in the United States, including Associates of Cape Cod (Falmouth, Massachusetts), BioWhittaker (Walkersville, Maryland), Charles River Endosafe Inc. (Charleston, South Carolina), Haemachem (St. Louis, Missouri), and Limuli Labs (House, New Jersey). Each of the five biomedical companies have unique bleeding methods, method of capture, distance and method of travel to bleeding lab, holding time and conditions, and methods of return most appropriate to their own setting and situation. Thus, the impact of the blood extraction processes on survival of the horseshoe crabs varies between operations. 
To harvest horseshoe crabs for biomedical use requires a special permit. Prior to 2001, biomedical companies were required to return all horseshoe crabs taken pursuant to this permit to the same location from which they were collected (Schrading et al., 1998). Currently, biomedical companies may sell their bled horseshoe crabs to the bait industry (ASMFC, 2001), although most bled horseshoe crabs are still returned to the ocean. Monthly reports are required on harvest numbers and percent mortality up to the point of release (including mortality occurring during harvest, shipping, handling and bleeding). In addition, in 1998 biomedical companies were required to evaluate the post-release mortality of the horseshoe crabs (Schrading et al., 1998).

\section{OTHER IMPORTANT USES OF THE HORSESHOE CRAB}

Since the early 1900s, the horseshoe crab has been used as a laboratory research animal model to study the structure, physiology, and function of its large eye and simple nervous system (two large brain ganglia). In addition, horseshoe crabs have been used by public aquaria and coastal educational centers in display and "touch tanks" to bring living marine organisms up-close to visitors. Most recently, the horseshoe crab and its eggs have been used by extension programs and educational programs in elementary schools to teach conservation, ecology, and environmental issues to school children.

\section{ECONOMIC IMPACTS}

The economic impacts of horseshoe crabs reported here were estimated by Industrial Economics, Incorporated for the United States Fish and Wildlife Service (Manion et al., 2000). Their findings, summarized in a report dated April 7, 2000 were the first to place an economic value on horseshoe crabs and are reported below.

Horseshoe crabs play a role in the economy of three diverse industries and user groups: wildlife viewing and birding enthusiasts together with the ecotourism industry, the biomedical industry, and the Atlantic Coast commercial eel and whelk (conch) pot fisheries. While it is recognized that the influence of any one of these industries on the economy at-large may be negligible, the impact is likely to be significant on a local scale with local economies dependent on these industries for jobs and spending.

Each spring, as vast quantities of horseshoe crabs spawn on beaches along Delaware Bay, thousands of bird-watchers congregate on the beaches. Here, the birders hope to witness the well-publicized phenomenon occurring as thousands of migratory shorebirds stop in Delaware Bay to feed on horseshoe crab eggs. The influx of bird-watching enthusiasts into the Delaware Bay areas contributes to the local economies, as the birders purchase recreation-related goods and services, including food, lodging, and equipment. It is estimated that the annual economic activity in the Cape May, New Jersey, area associated with spending on horseshoe crab-dependent eco-tourism ranges from $\$ 7$ million to $\$ 10$ million (1999 dollars). In addition, approximately 120 to 180 jobs are also associated with these industries. The annual social welfare value has been estimated to be between $\$ 3$ million and $\$ 4$ million. 
In contrast to the ecotourism industry, it is estimated that the whelk pot fishery contributes $\$ 11$ to $\$ 15$ million in annual output in the regions where this fishery is active. These include the following states: Massachusetts, Rhode Island, Connecticut, New York, New Jersey, Delaware, Maryland, and Virginia. The whelk pot fishery creates approximately 270 to 370 jobs in these areas. It is estimated that the social welfare value of the whelk pot fishery is approximately $\$ 9$ million. The American eel pot fishery does not rely on horseshoe crabs for bait as extensively as the whelk pot fishery, as alternative baits, including surf clams, are more effective in the eel pot fishery. The contribution of the eel pot fishery to the local economies in the MidAtlantic area is estimated to be $\$ 2$ million. Further, the eel pot fishery creates approximately 70 jobs in the Mid-Atlantic region. It is estimated that the total annual economic welfare of the eel fishery is approximately $\$ 12$ million. Combined, the conch and eel pot fisheries' annual economic welfare value is about $\$ 21$ million.

The United States Food and Drug Administration (FDA) requires pharmaceutical and biomedical manufacturers to use LAL in testing end-products for endotoxins before releasing them to the market. Annual revenues are estimated to be $\$ 60$ million. Of the five companies currently producing LAL, three dominate the world market for LAL. These three companies are located in Falmouth, Massachusetts, Walkersville, Maryland; and Charleston, South Carolina. It is estimated that the contribution of the LAL industry to each of these regional economies ranges from $\$ 22$ million to $\$ 35$ million, or $\$ 73$ million to $\$ 96$ million in total. In addition, the industry creates approximately 145 to 195 jobs in each region, or approximately 440 to 540 jobs overall. The annual social welfare value has been estimated to be at least $\$ 150$ million. This is partially due to the inelastic demand for LAL due to the requirements of the FDA and the absence of any alternatives to LAL.

By combining the aforementioned industries/user groups, estimates of total economic contributions from the horseshoe crab can be determined. Overall, the horseshoe crab contributes between $\$ 93$ and $\$ 123$ million to regional economies of the Atlantic Coast. This results in between 900 to 1160 jobs overall, as well as a national economic welfare contribution of at least $\$ 175$ million. As stated in the report by Manion et al. (2000), which we summarize above, clearly the horseshoe crab is not only ecologically important, but economically important as well.

\section{ALTERNATIVES TO HORSESHOE CRABS}

With concern rising as to the status of the horseshoe crab population and their increased use, alternatives are being explored in an attempt to reduce the needed number of horseshoe crabs. While it is thought that migratory shorebirds may supplement their diet with food sources other than horseshoe crab eggs, most of the attention on alternatives has been focused on reducing the number of horseshoe crabs used in both the biomedical industry and the commercial fishery.

\section{A. THE BIOMEDICAL INDUSTRY}

The use of Limulus Amebocyte Lysate (LAL) for testing biomedical products is not the only way to test for sterility. Prior to the use of LAL, compounds were tested for 
presence of endotoxin in a variety of ways that involved living animals or living parts of animals (Mikkelsen, 1988). The most widely used method involved the injection of the test solution into the bloodstream of rabbits, and then monitoring the rabbits' temperatures over a period of $3 \mathrm{~h}$ (Novitsky, 1984). A test solution that caused a fever in rabbits was rejected and those pharmaceutical agents were not released for use (Novitsky, 1984). Other methods involved death in bird embryos, provoking of abortion, and the production of skin inflammation and damage to rodent sarcomas (Mikkelsen, 1988).

Each of the five biomedical companies currently bleeding horseshoe crabs have experimented with developing a synthetic compound that mimics the behavior of LAL. However, a compound that is as successful at detecting endotoxin has yet to be found. Research in this area is continuing, but it is not known when a successful compound might be developed or implemented. The culturing of cells to produce LAL has also been tried (Loeb, 1917; Pearson and Woodland, 1978). While there have been several reports of limited success, commercial production is not viable at this time.

\section{B. THE HORSESHOE CRAB COMMERCIAL FISHERY}

Efforts are currently underway to look for alternatives to horseshoe crabs as bait. It is known that eels will feed on baits other than horseshoe crabs, but it is estimated to take up to 1 week for them to become accustomed to a new bait (K. Ferrari, personal communication, 2000). Thus, fishermen continue to use horseshoe crabs as bait for eel and conch. Efforts have been made to decrease the number of horseshoe crabs used as bait. One way is to encase them in bait bags. Bait bags are polyethylene quarter-inch mesh bags that can hold the horseshoe crabs during the trawling process (B. Fisher, personal communication, 2000). These can be used as opposed to the traditional method of placing the horseshoe crab on a stake. The use of bait bags prolongs the life of the bait by lifting it off the seafloor and preventing predators, including crabs, snails, and copepods, from consuming the bait. Thus, smaller numbers of horseshoe crabs can be used. Traditionally, commercial fishermen use one female horseshoe crab or two male horseshoe crabs as bait (B. Fisher, personal communication, 2000). A study done by Bob Fisher at the Virginia Institute of Marine Science (VIMS) looked at the efficiency of using bait bags with smaller quantities of bait. He found that by reducing the amount of bait used by half (i.e., by using $1 / 2$ female or 2 half's of male horseshoe crabs) and utilizing the bait bags, the catch rate of whelk declined by 4 to $6 \%$ (B. Fisher, personal communication, 2000). Decreasing the amount of bait further resulted in more substantial declines in catch rate. The use of bait bags and decreased amount of horseshoe crab bait has been implemented into Virginia Marine Resources Commission policy, and commercial whelk fishers are now required to use the bait bags.

Aside from decreasing the numbers of horseshoe crabs used through the use of bait bags, other experiments have looked at using alternative media as bait for eel and conch. One study investigated using waste from the local surf clam fishery. Generally, the waste is sent to the landfill, making this a very cost-effective alternative. However, this study showed a significant decrease in the number of conch caught with this bait as opposed to the traditional use of horseshoe crabs (B. 
Fisher, personal communication, 2000). A variety of other substances for bait have also been tested, including the cownose ray, surf clams, green crab, Mercenaria clam, haemolymph left over from the horseshoe crab blood extraction process, and cell-debris left over from the lysate process. None of these substances have had the same attraction power as the horseshoe crab (B. Fisher, personal communication, 2000). Fishermen have also been experimenting with alternative bait. In Maine, a ground salted fish encased in a "bait sock" is used in the pots in place of a horseshoe crab. In the northern states, some fishermen are using clams for bait, but clam flesh spoils too quickly in warmer waters (south of New York), making this an unusable alternative in the southern states. In the North Carolina eel fishery, a survey by the division of marine fishery of eel pot fishermen found that shrimp heads, blue crabs, and cheese ends were being used as bait. Horseshoe crabs were not being used at all (K. Ferrari, personal communication, 2000). Lastly, researchers have been experimenting with synthesizing an artificial bait from a chemical cue found in the eggs of horseshoe crabs. It is believed that this compound is what attracts eel and conch to the horseshoe crab (K. Ferrari, personal communication, 2000). However, the molecular size and complexity of this attractant make it unlikely that a cost-effective synthetic version of it can be developed (K. Ferrari, personal communication, 2000). The attractant compound is also found in the haemolymph, a component of the horseshoe crab's blood, although in diluted quantities. Haemolymph is available year round as a byproduct of the biomedical companies' blood-extraction process. Research is currently underway involving incorporating this chemical cue from the haemolymph into a cost-effective bait. If successful, artificial bait could prove to be a sound alternative to horseshoe crabs in the eel and conch fisheries.

\section{HORSESHOE CRAB STATUS AND MANAGEMENT}

The management of the horseshoe crab harvest has come under intense scrutiny in recent years as environmentalists became increasingly concerned about the impact of the declining horseshoe crab population on migrating shorebirds. News stories about horseshoe crabs have appeared in local, regional, and national media. While the horseshoe crab with its ancient past and its conflicting stakeholders makes an excellent story, the management of the resource is no less interesting. How do you manage a multiple use resource in the absence of good scientific information? In this section we review the management process that governs the horseshoe crab harvest, our knowledge of the population status and population dynamics, the recent management history, and the future of horseshoe crab management.

\section{A. THE MANAGEMENT PROCESS}

In federal waters (greater than 3 nautical miles from shore), horseshoe crabs are managed by the National Marine Fisheries Service (NMFS). In non-federal waters, horseshoe crabs are managed by the Atlantic States Marine Fisheries Commission (ASMFC). The ASMFC was created in 1942 by Congress and the 15 Atlantic coast states to assist in management and conservation of shared coastal fishery resources. Because marine fish species move among many states, successful management can 
only occur when all states work together. States involved in the ASMFC include (from north to south): Maine, New Hampshire, Massachusetts, Rhode Island, Connecticut, New York, New Jersey, Pennsylvania, Delaware, Maryland, Virginia, North Carolina, South Carolina, Georgia, and Florida. Each state is represented on the Commission by three Commissioners. These include the director of the state's marine fisheries management agency, a state legislator, and an individual appointed by the state's governor that represents fishery interests. The commissioners participate in deliberations in the commissions' main policy arenas: interstate fisheries management, research and statistics, habitat conservation, and sport fish restoration. The three commissioners cast a single vote on behalf of the state.

Management of horseshoe crabs is performed by the Interstate Fisheries Management Program (ISFMP) of the ASMFC. The ISFMP began in 1981, with the signing of a cooperative agreement with NMFS. Some major objectives of this program include (1) determining priority species, (2) developing, monitoring, and reviewing fishery management plans for priority species, (3) recommending management measures to states, regional fishery management councils, and the federal government concerning priority species, and (4) monitoring compliance with approved fishery management plans.

The ISFMP operates under the direction of the ISFMP Policy Board and species management boards. The ISFMP Policy Board is comprised of one representative from each member state, the District of Columbia, the Potomac River Fisheries Commission, the NMFS, and the U.S. Fish and Wildlife Service (USFWS). The Policy Board is responsible for giving guidance and for maintaining consistency with the program's charter and between fishery management plans.

Species management boards exist for each of the species under management by the ASMFC. The horseshoe crab management board, like those for other species, is responsible for developing and implementing management plans for the horseshoe crab. To do so, the management board relies on input from both the Horseshoe Crab Technical Committee and an advisory panel.

The Horseshoe Crab Technical Committee (HCTC) is responsible for providing scientific advice to the horseshoe crab management board. The HCTC is composed of technical staff from states involved in the ASMFC, as well as representatives from NMFS, USFWS, and members of academia. They collect information and analyze data, look at the likely impacts of possible management actions, and make recommendations to the management board based on biology. One subcommittee of the HCTC is the Stock Assessment Subcommittee. The Stock Assessment Subcommittee is responsible for designing and implementing stock assessments, analyzing data obtained from stock assessments, and reporting their findings to the HCTC.

Whereas the HCTC makes recommendations to the management board based on science, the Horseshoe Crab Advisory Panel provides guidance to the management board from the viewpoint of the fishermen, industries, and interest groups involved. The Horseshoe Crab Advisory Panel is made up of representatives from both the commercial fishery and the biomedical industries as well as members of conservation organizations. Members of the Advisory Panel are appointed by the three Commissioners from each state. The Advisory Panel is expected to work out their internal differences and report a unanimous recommendation to the management board. 


\section{B. CURRENT STATUS}

Developing a successful horseshoe crab management strategy is dependent on having the needed time series of population dynamics information, including information about the status of the population. Unfortunately, despite the fact that horseshoe crabs have been fished for over 100 years, the typical data collected in any fishery for management purposes have only recently started to be collected for horseshoe crabs (Berkson and Shuster, 1999). As stated earlier, horseshoe crabs have been considered a "trash-fish", not worthy of limited agency resources (Berkson and Shuster, 1999). Only in recent years has there been an interest in their status and management. Without time series of relevant data, there has been pressure to use less than appropriate data to determine the population's status.

While there have been some recent attempts to evaluate the status of the horseshoe crab population, the methods used in these attempts have been flawed and deemed statistically unsound by an independent Peer Review Panel reviewing the available horseshoe crab stock assessment work (ASMFC, 1998).

Although various state and federal trawl surveys are available to review, the Peer Review Panel found them to be of little to no value for determining population status of horseshoe crabs (ASMFC, 1998). The surveys were multispecies finfish surveys that did not target horseshoe crabs, but included horseshoe crabs as bycatch. In many cases, the gear used in the trawl surveys included a device used to exclude horseshoe crabs from the catch. Captures of crabs were infrequent, and thus give uninformative data.

Annual spawning surveys have been conducted in the Delaware Bay region, but the results of these surveys were hampered by a lack of standardized methodology sufficient to produce any accurate indicators of horseshoe crab population levels (ASMFC, 1998). This is because the periodicity of the survey did not match the periodicity of spawning movements of horseshoe crabs, the number of beaches sampled was too limited, and sampling techniques were inconsistent over time (ASMFC, 1998).

Annual egg-count data from Delaware and New Jersey beaches were also examined by the Peer Review Panel. Because of insufficient and inconsistent sampling, the panel determined that the egg-count data were inadequate to permit a complete analysis.

The panel concluded that while no increasing or decreasing trend in horseshoe crab abundance could be shown from the data available, it was not because no trends existed, but because of the uninformative nature of the available data (ASMFC, 1998). Similarly, the panel found that the uninformative nature of the data made it impossible to identify whether the increase in commercial landings of horseshoe crabs has had an impact on the horseshoe crab population (ASMFC, 1998). Thus, as of 1998 there was little useful information available concerning the status of the horseshoe crab population.

The increased interest in horseshoe crabs is leading to increased efforts to gather the information needed for effective management. These include redesigned spawning surveys using a sound statistical design that were first implemented in 1999 (Smith et al., 2002). With only 2 years of data available from this survey, it is not possible to draw meaningful conclusions about horseshoe crab population status. 
However, as this survey continues and longer time-series of data are obtained, it will be possible to examine trends in spawning numbers.

In addition, it is now mandatory that commercial fishermen report their horseshoe crab landings, which will provide managers with much-needed harvest data. Catch sampling is also being conducted by both Maryland's Department of Natural Resources as well as the biomedical company BioWhittaker. Gradually, we are moving into an era where standard fisheries data will be collected on horseshoe crabs. This should provide some hope that it will be possible to design effective, scientifically based management strategies for this species.

\section{MANAGEMENT ACTIONS}

Management actions over the last 10 years have moved from nonexistent and ignored to highly restrictive and controversial. Although fished for over 100 years, the horseshoe crab fishery as late as 1990 remained unregulated. For the most part, management regulation came as a result of targeted political pressure from environmental groups concerned about how a declining horseshoe crab population would impact shorebirds.

Regulations began in the early 1990s when New Jersey, Delaware, and Maryland began implementing management measures that included permits, licenses, daily restrictions, area restrictions, and fees. The other Atlantic states remained unregulated. In 1996, Maryland began enacting area restrictions to specifically protect spawning seasons. Catch reporting also became mandatory in Maryland at this point.

In 1997, the ASMFC was tasked to develop a joint eel/horseshoe crab plan. At the same time, New Jersey and Delaware came under political pressure from environmental groups to shut the horseshoe crab fishery down. In response, New Jersey implemented a mobile gear prohibition and a moratorium. Delaware also took immediate action, implementing severe area restrictions. As a result of Delaware and New Jersey's restrictions, the fishery effort shifted to Maryland.

Maryland began experiencing the same political pressure previously felt by New Jersey and Delaware. In 1998, the Governor of Maryland took the rare move of signing an executive order directing the Natural Resources Department to limit catch to only those fishermen that caught horseshoe crabs in 1996. This eliminated the fishermen who had immigrated over the last year from Delaware and New Jersey. In addition, the overall quota in Maryland was reduced by $76 \%$ over the amount caught in 1996. Harvest was not allowed within 1 mile of the Atlantic Coast between April 1 through June 30, including Chesapeake and coastal bays. Landing limits were imposed to ensure that the fishery would continue year round. The horseshoe crab fishery in Maryland, Delaware, and New Jersey had become highly regulated in a very short period of time, in direct response to the new political pressure.

In 1998, the ASMFC effort also became more focused. The horseshoe crab management plan was separated from the eel/horseshoe crab earlier proposed. Tom O'Connell of Maryland DNR was brought on as the first Plan Coordinator. A horseshoe crab management plan was adopted by ASMFC in October of 1998. The focus of this initial plan was on monitoring rather than regulating. The lack of good 
fishery and population data precluded the development of a sound scientific management strategy. The plan called for spawning and egg surveys, mandatory catch reporting, studies on the use of horseshoe crabs by the biomedical industry, and habitat delineation. The plan required New Jersey, Delaware, and Maryland to maintain their harvest restrictions. The remaining ASMFC states, including Virginia, were left unregulated.

As a result of Maryland's new, strict fishery regulations, landings from Maryland shifted to Virginia, which remained unregulated. Virginia's landings averaged 200,000 horseshoe crabs in 1995 to 1997, then grew to over 1.2 million in 1998. It is widely believed that the majority of this catch came from ocean waters off of Delaware Bay and Maryland. Much of the catch came from conch dredges modified to catch horseshoe crabs.

Predictably, political pressure hit Virginia in the early part of 1999. The horseshoe crab management board of ASMFC failed to establish a coastwide or state specific quota in the early part of 1999 . Virginia set its quota at 710,000 to meet the demands of the conch fishery. This quota was well above the 200,000 horseshoe crabs landed annually on average in 1995 to 1997. ASMFC was still unwilling to impose quotas. Virginia easily met its 1999 quota.

Virginia's sharp increase in its landings infuriated the environmental groups. By the end of 1999 the management board began work on Addendum 1 to the management plan, implementing coastwide harvest restrictions. Environmentalists called for a 50\% reduction from the average landings during the 1995 to 1997 reference period. Fishermen called for a $0 \%$ reduction. Because of the lack of historical catch and population data, the Technical Committee was not able to recommend a scientifically based percentage reduction. The Addendum was approved in February of 2000. Beginning in 2000, landings were to be determined on a state by state basis, coastwide, by implementing a $25 \%$ reduction from the average landings in each state during the 1995 to 1997 reference period. This appeared to be a compromise between the positions of the environmentalists and the fishermen. In addition, the addendum encouraged Maryland, Delaware, and New Jersey to maintain their more stringent harvest restrictions.

All states, with the exception of Virginia, came into compliance by May. At that time, bait bags were introduced into the fishery, reducing the amount of horseshoe crabs needed for use as bait by half. Virginia loudly praised itself over its newly reduced quota reduction from 710,000 to 355,000, which resulted from the introduction of the bait bags. The new quota was still much greater than the ASMFC imposed quota of 152,000 , the $25 \%$ reduction over the 1995 to 1997 average catch required in the management plan. That is when the real battle began.

Virginia stated that Maryland, Delaware, and New Jersey were taking reductions much greater than $25 \%$ and that Virginia fishermen get their horseshoe crabs from the same population. As a result, Virginia argued that it should be able to go above its ASMFC imposed quota of 152,000 without the cumulative impact exceeding the total coastwide 25\% reduction. Virginia argued that the overall reduction would remain in tact if Virginia merely harvested its own allocation together with the uncaught crabs allocated to other states. Maryland, Delaware, and New Jersey argued that their more restrictive regulations were necessary as part of a risk averse management strategy. The risk averse strategy would be eliminated if Virginia could catch the horseshoe crabs they were trying to protect. 
The ASMFC states, with the exception of Virginia, understood that Amendment 1 called for a $25 \%$ reduction over base period levels in combination with the continuation of the more restrictive management measures implemented by Maryland, Delaware, and New Jersey. Virginia's argument was dismissed and, as a result, Virginia was voted to be out of compliance with the management plan. ASMFC asked the U.S. Secretary of Commerce to find Virginia out of compliance and shut down Virginia's fishery. The Secretary of Commerce conducted an analysis and agreed to impose a moratorium on Virginia's horseshoe crab fishery in late October 2000.

At a management board meeting prior to October 2000, Virginia offered to come into compliance if the management board would agree to an addendum allowing voluntary quota transfers between states. A voluntary policy would require a state's consent to transfer an unused quota. This was a face-saving compromise of sorts for Virginia. The management board agreed to work on the addendum, and Virginia quickly came into compliance, dropping down to the 152,000 quota originally imposed. The Secretary of Commerce rescinded the order to close Virginia's fishery. Virginia shut down their horseshoe crab fishery for the rest of the year because their quota had already nearly been met.

Addendum 2 to the horseshoe crab management plan was approved in April of 2001, allowing voluntary transfers in quotas, but only in cases where certain criteria are met. The states who are parties to any proposed transfer must show how the transfer will impact the horseshoe crab population using the best available information on the resulting impacts to the horseshoe crab population, the shorebird population, and the biomedical industry. This requires information on the genetics of the populations, population status, and other data not currently available. For that reason it is unlikely that quota transfers will happen on a large scale in the foreseeable future. Transfers on a small scale may go forward if it is obvious that they will have no overall impact.

One other major management action was introduced in the midst of the 2000 harvest controversy. In May of 2000, Dr. Carl N. Shuster, Jr. submitted a proposal to the management board to have a horseshoe crab sanctuary in the mouth of Delaware Bay. Dr. Shuster is the world's leading authority on the American horseshoe crabs, having written the majority of the scientific literature on the species. The sanctuary proposal gained support for two main reasons. First, the state of New York, under pressure from environmental groups, saw the sanctuary as a way to further protect the horseshoe crab resource without further reducing its own harvest. Second, many of the ASMFC states understood that Virginia was not going to comply with Amendment 1, the 25\% catch reductions, and that much of Virginia's catch could be coming from the Delaware Bay. The sanctuary seemed to be another way to protect the Delaware Bay population. Many of the states felt that the Delaware Bay sanctuary would not have been necessary if all of the states would have immediately come into compliance, but with the very real threat of overharvest, the sanctuary seemed prudent. The sanctuary was approved within Addendum 1 as a recommendation to the National Marine Fisheries Service. The sanctuary plan was supported by the Clinton Administration where it came under review. The Delaware Bay sanctuary officially became the "Dr. Carl N. Shuster, Jr. Horseshoe Crab Reserve" on March 7, 2001 (Figure 7). This is a very fitting tribute to the world's foremost horseshoe crab researcher and educator of horseshoe crab issues.

The western boundary of the reserve is where the federal waters begin, 3 miles offshore from the mouth of Delaware Bay. The northernmost boundary is 30 nautical 


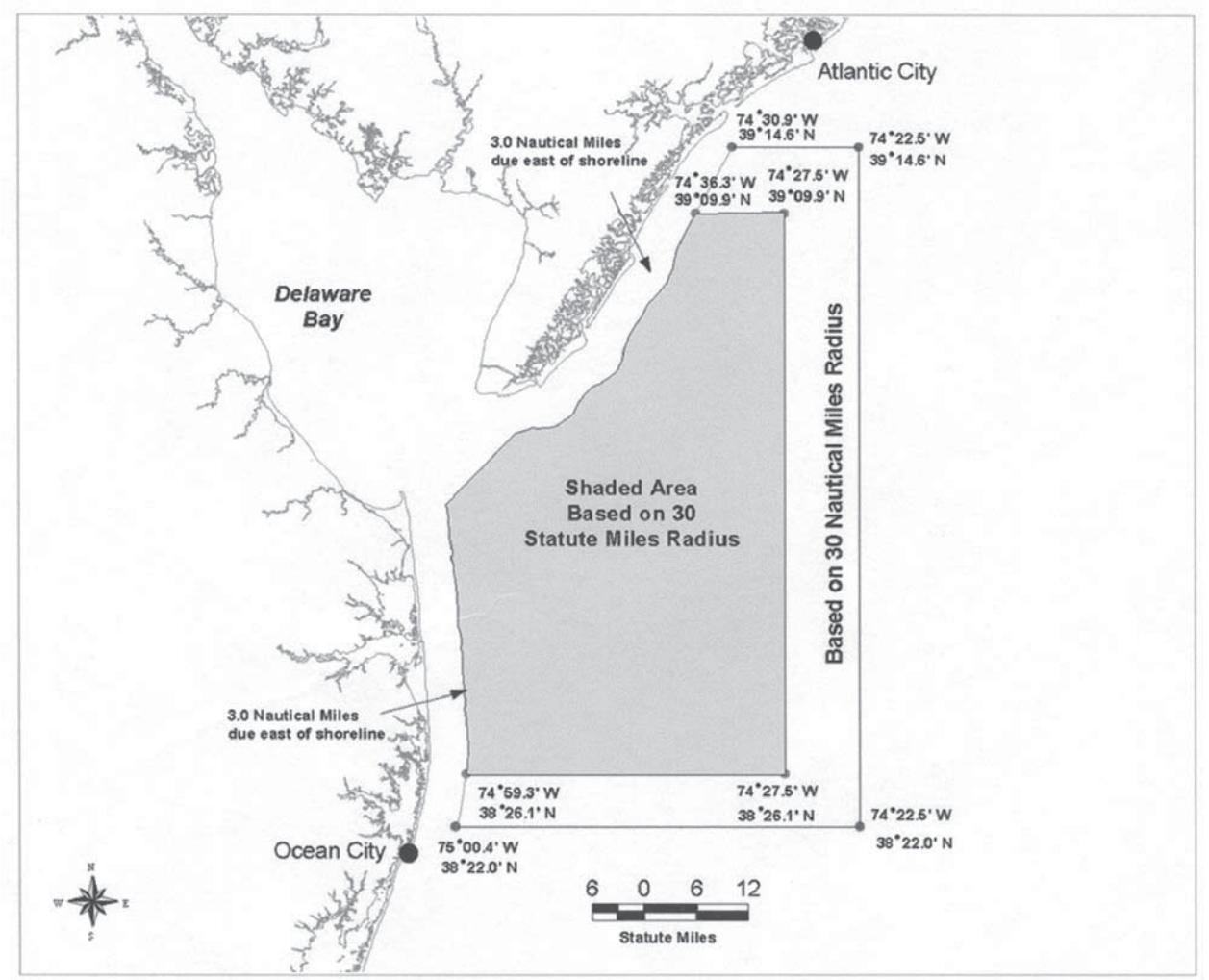

FIGURE 7. Map of Carl N. Shuster, Jr. Horseshoe Crab Reserve.

miles north to a location just south of Atlantic City. The southernmost boundary is 30 nautical miles to a location just north of Ocean City, Maryland. The eastward boundary is 30 nautical miles east of Delaware Bay. No commercial fishing for horseshoe crabs is allowed within this reserve.

The total landings of horseshoe crabs in 2000 represented an overall $40 \%$ reduction in landing over the 1995 to 1997 base period. Only one state went over its assigned quota, New York, and it went over its quota considerably. The overage will be deducted from New York's 2001 quota.

There was also one major clarification of the plan with regard to the biomedical industry. In the past, biomedical companies collecting under a scientific collection permit had to return bled horseshoe crabs alive to the ocean. Beginning in 2001, biomedical companies can take horseshoe crabs from the commercial bait fishery against a state's quota, bleed them, and then return them to the bait fishery. This policy gives the biomedical companies more options for securing needed horseshoe crabs and has the potential to reduce the total of horseshoe crabs caught by the biomedical companies.

\section{STOCK ASSESSMENT PLAN}

To this point we have discussed the past and present management of the horseshoe crab population. Past management really was no management, with the 
species being ignored and going unregulated. The period stretching from nearly 10 years ago to the near future is a time of precautionary management in the absence of informative data, while data needed to scientifically manage the population begin to be collected. Where is the future of horseshoe crab management likely to go?

The Horseshoe Crab Stock Assessment Committee (SAC) developed a conceptual framework for the assessment of horseshoe crab stocks in the mid-Atlantic region in 2000 (HCSAC, 2000). The SAC first considered the life history of the species together with the kinds of data that could potentially be collected and then reviewed a wide array of available stock assessment approaches. The SAC endorsed the catchsurvey model developed by Collie and Sissenwine (Collie and Sissenwine, 1983). This method relates the number of adults and recruits in 1 year to the number of adults in the following year. It permits the estimation of abundance and fishing mortality rates. The method has been used previously in the assessment of Delaware Bay blue crab stocks (Hesler and Kahn, 1999).

There are several critical assumptions for using this method. First, once horseshoe crabs reach sexual maturity, they no longer molt. Second, horseshoe crabs that are 1 year or less from entering their initial spawning season are identifiable and discernable from those that have spawned at least once. The first assumption is believed to be true (Botton and Ropes, 1988). The second assumption is less certain, but methods are being developed (which will likely involve carapace appearance and inspection for the presence of eggs), which will increase the likelihood of meeting this assumption.

This stock assessment method requires a range of information. An estimate of natural mortality for adults would be required and could be crudely estimated, using the presumed maximum life expectancy of 20 years. The application of the method requires the collection of annual commercial harvest data from the fisheries, which has taken place for several years now and is expected to continue. Data are also needed on the proportions of newly recruited animals (horseshoe crabs spawning for the first time) to adults in the commercial fishery. This requires the development of a technique to quickly and reliably identify newly recruited individuals. Finally, and most importantly, annual indices of population abundance for the recruit and the adult spawning stages, collected by standardized research surveys, are required. This information has not been collected in the past and would require the establishment of an annual horseshoe crab benthic trawl survey. Trawl surveys have collected data on horseshoe crabs in the past, but, as mentioned earlier, horseshoe crabs have never been the targeted species and these surveys often included horseshoe crab excluder devices to preclude the capture of horseshoe crabs (ASMFC, 1998).

With funding from Delaware, Maryland, and New Jersey, ASMFC working with the National Fish and Wildlife Foundation, has contracted with the Horseshoe Crab Research Center at Virginia Tech to design the annual trawl survey required for the catch-survey method. Funding to conduct the annual survey, once designed, has not been identified, and the annual amount is expected to be substantial. A move to scientifically based management of horseshoe crabs is dependent on following the recommendations of the SAC. One or more agencies will need to step up and take responsibility for the annual surveys. 


\section{E. MANAGEMENT CONCLUSIONS}

The story of horseshoe crab management is a familiar one in the natural resource world. For years, the resource was exploited because of the absence of monitoring or regulations. An environmental crisis (real or perceived) hit, forcing managers to begin managing the resource. Without any data, management policies were not based on science, but rather a combination of the precautionary principle (Costanza and Cornwell, 1992) and the art of compromise.

Fortunately, two things are now working in the horseshoe crabs' favor. First, data needed to properly manage this resource are now being collected and a benthic trawl survey required to conduct stock assessment is being designed. However, it is likely that a minimum of 5 to 10 years of data collection will be required before these data will allow for accurate stock assessment. Second, a functional management process is well established for the species. The Atlantic States Marine Fisheries Commission regularly manages species crossing jurisdictional lines. The rules of the process have been long established and accepted.

The horseshoe crab is moving on a path from being ignored to being scientifically managed. Reaching the endpoint is dependent on two things: sufficient time to collect informative data and sufficient commitment to collect the data. Everyone involved must realize that there is no quick fix to the horseshoe crab issue. As with any fishery, effective management of the horseshoe crab will require ongoing research and monitoring. Given that the fishery is over 100 years old, we are far behind where we ought to be, and we need the time and resources to catch up. Political, economic, and social issues regarding the horseshoe crab resource will remain even after accurate data are available for management. However, once accurate data is available, managers will be aware of, and able to project, the likely impacts of alternative management options.

\section{CONCLUSION}

Inhabitants of the East Coast are very familiar with the horseshoe crab. Parents have been taking their children to see their annual spawning migration for as long as can be remembered. Biomedical companies are familiar with the horseshoe crab for its incredible ability to detect endotoxins, which saves lives every day. Fishermen have been familiar with the horseshoe crab for over 100 years, providing an important component of the coastal economy. Environmentalists are familiar with the horseshoe crab for the food they provide to migrating shorebirds, ensuring they complete their migration to nest and begin the life cycle anew. Economists have become recently familiar with the horseshoe crab for the $\$ 93$ to $\$ 123$ million it provides to the regional economy. This is a species that is economically, ecologically, and medically important.

Despite the fact that so many are familiar with the horseshoe crab, we really do not know that much about it. Only recently has the population's true value and potentially fragile condition been acknowledged. In this article we have tried to lay out what is known about the horseshoe crab and what we still need to know to be able to manage, allocate, and conserve this important 
species. As with any managed species, resources will be needed to provide the research and monitoring required. The horseshoe crab has changed from being an anonymous resource to an essential resource in a period of 10 to 20 years. Can we adequately manage this resource without a baseline of scientific information? Will the resources be available to collect the scientific information needed to manage the resource? We do not have the answers to these questions at this time, but perhaps another review article in 10 to 20 years will provide these answers.

\section{ACKNOWLEDGMENTS}

The writing of this article was made possible with the support of BioWhittaker, Inc., a Cambrex company. We thank Carl N. Shuster, Jr. for teaching us about the horseshoe crab and encouraging us to continue learning about this unique species. We want to thank Dr. William McCormick, Dr. Ron Berzofsky, Charles Routzahn, and Shawn Cavanagh for the support and friendship we have been given through the years from BioWhittaker, Inc. Tom O'Connell was instrumental in providing us with up-to-date information regarding the horseshoe crab and its management. We wish to acknowledge the following for their help and support in writing this article and in our horseshoe crab explorations: Mike Millard, Stewart Michels, Dr. David Smith, Peter Himchak, Jeffrey Brust, Dr. Lisa Kline, Lewis Gillingham, Mark Thompson, and Sheila Eyler. We also wish to thank Dr. Jim Fraser, Dr. David Hata, Lenka Hurton, Brent Bowden, and Scott Klopfer of Virginia Tech for their participation in our ongoing collaborative research.

\section{REFERENCES}

ASMFC. 1998. Horseshoe Crab Peer Review. Atlantic States Marine Fisheries Commission, Richmond, Virginia.

ASMFC. 2001. Horseshoe Crab Fishery Management Plan, Addendum II, Section D. Atlantic States Marine Fisheries Commission, Washington, D.C.

Berkson, J. M. and C.N. Shuster, Jr. 1999. The horseshoe crab: the battle over a true multiple use resource. Fisheries, 24: 6-10.

Botton, M. L. 1984a. Diet and food preferences of the adult horseshoe crab, Limulus polyphemus, in Delaware Bay, New Jersey, USA. Marine Biology, 81: 199-207.

Botton, M. L. 1984b. Importance of predation by horseshoe crabs, Limulus polyphemus, to an intertidal sand flat community. Journal of Marine Research, 42: 139-161.

Botton, M. L. 1995. Horseshoe crab. pp. 51-57 In: Living Resources of the Delaware Estuary. (L. E. Dove and R. M. Nyman, Eds.). The Delaware Estuary Program. U.S. Environmental Protection Agency. Philadelphia, Pennsylvania.

Botton, M. L. and H. H. Haskin. 1984. Distribution and feeding of the horseshoe crab, Limulus polyphemus, on the continental shelf off New Jersey. Fisheries Bulletin, 82: 383-389.

Botton, M. L. and R.E. Loveland. 1989. Reproductive risk: high mortality associated with spawning in horseshoe crabs (Limulus polyphemus) in Delaware Bay, USA. Mar. Biol. (Berl.), 101: 143-151.

Botton, M. L. and R.E. Loveland. 1993. Predation by herring gulls and great black-backed gulls on horseshoe crabs. Wilson Bulletin, 105: 518-521. 
Botton, M. L., R. E. Loveland, and T. R. Jacobsen. 1992. Overwintering by trilobite larvae of the horseshoe crab, Limulus polyphemus, on a sandy beach of Delaware Bay (New Jersey, USA). Marine Ecology Progress Series, 88: 289-292.

Botton, M. L., R. E. Loveland, and T. R. Jacobsen. 1994. Site selection by migratory shore birds in Delaware Bay, and its relationship to beach characteristics and abundance of horseshoe crab (Limulus polyphemus) eggs. Auk, 111: 605-616.

Botton, M. L. and J. W. Ropes. 1987. Populations of horseshoe crabs, Limulus polyphemus, on the northwestern Atlantic continental shelf. Fishery Bulletin, 85: 805-812.

Botton, M. L. and J.W. Ropes. 1988. An indirect method for estimating longevity of the horseshoe crab (Limulus polyphemus) based on epifaunal slipper shells (Crepidula fornicata). Journal of Shellfish Resources, 7:407-412.

Brockmann, H. J. 1990. Mating behavior of horseshoe crabs, Limulus polyphemus. Behavior, 114: 206-220.

Brockmann, H. J. 1996. Satellite male groups in horseshoe crabs, Limulus polyphemus. Ethology, 102: 1-21.

Brockmann, H. J. and D. Penn. 1992. Male mating tactics in the horseshoe crab. Limulus polyphemus. Animal Behaviour, 44: 653-665.

Castro, G. and J. P. Myers. 1993. Shorebird predation on eggs of horseshoe crabs during spring stopover on Delaware Bay. The Auk, 110: 927-930.

Castro, G., J. P. Myers, and A. R. Place. 1989. Assimilation efficiency of sanderling (Calidris alba) feeding on horseshoe crab (Limulus polyphemus) eggs. Physiological Zoology, 62: $716-731$.

Clark, K. 1996. Horseshoe crabs and the shorebird connection. pp. 23-25. In: Proceedings of the horseshoe crab forum: status of the resource. (Farrell, J. and C. Martin, Eds.). University of Delaware Sea Grant College Program, Lewes, Delaware.

Clark, K. E., L. J. Niles, and J. Burger. 1993. Abundance and distribution of migrant shorebirds in Delaware Bay. Condor, 95: 694-705.

Collie, J. S. and M. P. Sissenwine. 1983. Estimating population size from relative abundance data measured with error. Canadian Journal of Fisheries and Aquatic Science, 40: 18711879.

Costanza, R. and L. Cornwell. 1992. The 4P approach to dealing with scientific uncertainty. Environment, 34: 12-20, 42.

deSylva, D. P., F. A. Kalber, Jr., and C. N. Shuster, Jr. 1962. Fishes and ecological conditions in the shore zone of the Delaware River estuary, with notes on other species collected in deeper water. University of Delaware Marine Labs. Report 5. Lewes, Delaware.

Dunne, P., D. Sibley, C. Sutton, and W. Wander. 1982. 1982 aerial shorebird survey of Delaware Bay. Records of New Jersey Birds, 8: 68-75.

Farrell, J. and Martin, C. (Eds.) 1996. Proceedings of the horseshoe crab forum: Status of the resource. University of Delaware Sea Grant College Program, Lewes, Delaware.

FERC. 1979. The Circulatory System and Blood of the Horseshoe Crab. A review. Federal Energy Regulatory Commission, United States Department of Energy, Washington, D.C.

Fowler, H. W. 1908. The king crab fisheries in Delaware Bay. Annual report of the New Jersey State Museum, 1907: 113-119 + pls. 59-65.

Hassler, C. and H. J. Brockmann. 2001. Evidence for use of chemical cues by male horseshoe crabs when locating nesting females (Limulus polyphemus). Journal of Chemical Ecology, 27: 2319-2335.

HCSAC. 2000. A conceptual framework for the assessment of horseshoe crab stocks in the mid-Atlantic region. Horseshoe Crab Stock Assessment Committee, Atlantic States Marine Fisheries Commission. Washington, D.C.

HCTC. 1998. Status of the horseshoe crab (Limulus polyphemus) population of the Atlantic coast. Horseshoe Crab Technical Committee, Atlantic States Marine Fisheries Commission. Washington, D.C. 
Herzog, E. D. and R. B. Barlow. 1992. The Limulus-eye view of the world. Visual Neuroscience, 9: 571-580.

Herzog, E. D., M. K. Powers, and R. B. Barlow. 1996. Limulus vision in the ocean day and night: Effects of image size and contrast. Visual Neuroscience, 13: 31-41.

Hesler, T. E. and D. M. Kahn. 1999. Stock assessment of Delaware Bay blue crab, Callinectes sapidus, for 1999. Delaware Department of Natural Resources and Environmental Control, Division of Fish and Wildlife. Document Number 40-05/99/02/01. Dover, Delaware.

Jegla, T. C. and J. D. Costlow. 1982. Temperature and salinity effects on development and early posthatch stages of Limulus. pp. 103-113. In: Physiology and biology of horseshoe crabs: studies on normal and environmentally stressed animals. (Boneventura, J., C. Bonaventura, and S. Tesh, Eds.). New York, Alan R. Liss, Inc.

Keinath, J. A., J. A. Musick, and R. A. Byles. 1987. Aspects of the biology of Virginia's sea turtles: 1979-1986. Virginia Journal of Science, 38:.329-336.

Loeb, L. 1917. On the factors which determine the movements of tissues in culture media. Journal of Medical Research, 37:.75-99.

Loveland, R. E. and M. L. Botton. 1992. Size dimorphism and the mating system in horseshoe crab, Limulus polyphemus. Animal Behavior, 44:.907-916.

Loveland, R. E., M. L. Botton, and C. N. Shuster, Jr. 1996. Life history of the American horseshoe crab (Limulus polyphemus L.) in Delaware Bay and its importance as a commercial resource. pp. 15-22. In: Proceedings of the horseshoe crab forum: status of the resource. (Farrell, J. and C. Martin, Eds.). Lewes, Delaware: University of Delaware Sea Grant College Program.

Manion, M. M., R. A. West, and R. E. Unsworth. 2000. Economic Assessment of the Atlantic Coast Horseshoe Crab Fishery. Division of Economics, U.S. Fish and Wildlife Service, Arlington, Virginia.

Manton, S. M. 1977. The Arthropoda: habits, functional morphology, and evolution. Clarendon Press.

Mikkelsen, T. 1988. The Secret in the Blue Blood, Science Press.

Myers, J. P. 1981. Conservation of migrating shorebirds: staging areas, geographic bottlenecks, and regional movements. American Birds, 37: 23-25.

Myers, J. P. 1986. Sex and gluttony on Delaware Bay. Natural History, 95: 68-77.

Myers, J. P., R. I. G. Morrison, P. Z. Antas, B. A. Harrington, T. E. Lovejoy, M. Sallaberry, S. E. Senner, and A. Tarak. 1987. Conservation strategy for migratory species. Am. Sci., 75:19-26.

Novitsky, T. J. 1984. Discovery to commercialization: the blood of the horseshoe crab. Oceanus, 27: 13-18.

Pearson, F., and E. Woodland. 1978. The in vitro cultivation of limulus amebocytes. pp. 93102. In: Biomedical applications of the horseshoe crab (Limulidae): Proceedings of a symposium held at Marine Biological Laboratory, Woods Hole, Massachusetts. (Cohen, E., Ed.). New York, Alan R. Liss, Inc.

Penn, D. and H. J. Brockmann. 1994. Nest-site selection in the horseshoe crab, Limulus polyphemus. Biological Bulletin, 187: 373-384.

Penn, D. and H. J. Brockmann. 1995. Age-biased stranding and righting in horseshoe crabs, Limulus polyphemus. Animal Behavior, 49: 1531-1539.

Pierce, J. C., G. Tan, and P. M. Gaffney. 2000. Delaware Bay and Chesapeake Bay populations of the horseshoe crab (Limulus polyphemus) are genetically distinct. Estuaries, 23: 690698.

Powers, M. K., R. B. Barlow, and L. Kass. 1991. Visual performance of horseshoe crabs day and night. Visual Neuroscience, 7: 179-190.

Riska, B. 1981. Morphological variation in the horseshoe crab, Limulus polyphemus. Evolution, 35: 647-658. 
Rudloe, A. 1983. The effect of heavy bleeding on mortality of the horseshoe crab, Limulus polyphemus, in the natural environment. Journal of Invertebrate Pathology, 42: 167-176.

Rudloe, J. 1979. Time of the turtle. New York: Alfred A. Knopf.

Saunders, N. C., L. G. Kessler, and J. C. Avise. 1986. Genetic variation and genetic differentiation in mitochondrial DNA of the horseshoe crab, Limulus polyphemus. Genetics, 112: 613-627.

Schrading, E., T. O'Connell, S. Michels, and P. Perra. 1998. Interstate Management Plan for Horseshoe Crab. Atlantic States Marine Fisheries Commission, Washington D.C.

Scott, N. J., Jr. and R. A. Seigel. 1992. The management of amphibians and reptile populations: Specific priorities and methodological and theoretical constraints. pp. 343-368. In: Wildlife 2001: Populations. (McCullough, D. R. and R. H. Barrett, Eds.). London, Elsevier Applied Science.

Sekiguchi, K. (Ed.) 1988. Biology of Horseshoe Crabs. Science House Co., Ltd.

Sekiguchi, K., Y. Yamamichi, and J. D. Costlow. 1982. Horseshoe crab development studies I. Normal embryonic development of Limulus polyphemus compared with Tachypleus tridentatus. pp. 53-73. In: Physiology and Biology of Horseshoe Crabs: Studies on Normal and Environmentally Stressed Animals. (Boneventura, J., C. Bonaventura, and S. Tesh, Eds.). New York: Alan R. Liss, Inc.

Selander, R. K., S. Y. Yang, R. C. Lewontin, and W. E. Johnson. 1970. Genetic variation in the horseshoe crab (Limulus polyphemus), a phylogenetic "relic". Evolution, 24: 402-414.

Shuster, C. N., Jr. 1950. Observations on the natural history of the American horseshoe crab, Limulus polyphemus. Woods Hole Oceanographic Inst. Contr., 564: 18-23.

Shuster, C. N., Jr. 1953. Odyssey of the horseshoe "crab". Audubon, 55: 162-163, 167.

Shuster, C. N., Jr. 1958. On morphometric and seriological relationships within the Limulidae, with particular reference to Limulus polyphemus (L.). Dissertation Abstracts, 18: 371372.

Shuster, C. N., Jr. 1978. Distribution of the American horseshoe crab, (Limulus polyphemus (L.). pp. 3-26. In: Biomedical Applications of the Horseshoe Crab (Limulidae). (Cohen, E., Ed.). New York: Alan R. Liss, Inc.

Shuster, C. N., Jr. 1982a. A pictorial review of the natural history and ecology of the horseshoe crab, Limulus polyphemus, with reference to other limulidae. pp. 1-52. In: Physiology and Biology of Horseshoe Crabs: Studies on Normal and Environmentally Stressed Animals. (Bonaventura, J., C. Bonaventura, and S. Tesh, Eds.). New York: Alan R. Liss, Inc.

Shuster, C. N., Jr. 1982b. Xiphosurida. pp. 766-770. In: Encyclopedia of Science and Technology. McGraw-Hill.

Shuster, C. N., Jr. and M. L. Botton. 1985. A contribution to the population of horseshoe crabs, Limulus polyphemus (L.), in Delaware Bay. Estuaries, 8: 63-372.

Smith, D. R., P. S. Pooler, B. L. Swan, S. Michels, W. R. Hall, P. Himchak, and M. Millard. 2002. Spatial and temporal distribution of horseshoe crab (Limulus polyphemus) spawning in Delaware Bay: implications for monitoring. Estuaries (in press).

Thompson, M. 1998. Assessments of the population biology and critical habitat for the horseshoe crab, Limulus polyphemus, in the South Atlantic Bight. M.S. Thesis. University of Charleston, Charleston, South Carolina.

Tiegs, O. W. and S. M. Manton. 1958. The evolution of the Arthropoda. Biological Review, 33: 255-338.

Walls, E.A. 2001. A horseshoe crab demographic study. M.S. Thesis. Virginia Polytechnic Institute and State University, Blacksburg, Virginia.

Walls, E. A. and J. M. Berkson. 2000. Effect of blood extraction on the mortality of the horseshoe crab, Limulus polyphemus. Virginia Journal of Science, 51: 195-198.

Wyse, G. A. and N. K. Dwyer. 1973. The neuromuscular basis of coxal feeding and locomotory movements in Limulus. Biological Bulletin, 144: 567-579. 